\title{
THE QUEST FOR NOMINAL AND REAL CONVERGENCE THROUGH INTEGRATION IN EUROPE AND LATIN AMERICA
}

Enrique Alberola, Ana Buisán and

Santiago Fernández de Lis

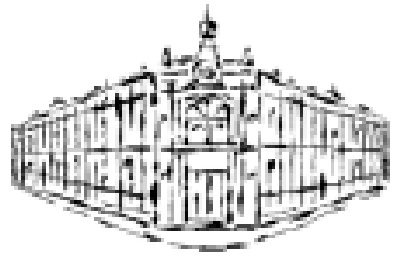

Banco de España - Servicio de Estudios Documento de Trabajo n. ${ }^{\circ} 0213$ 


\title{
The quest for nominal and real convergence through integration in Europe and Latin America
}

\author{
Enrique Alberola, Ana Buisán, Santiago Fernández de Lis ${ }^{1}$ \\ Banco de España
}

\footnotetext{
${ }^{1}$ This paper was prepared for presentation at the Preparatory Workshop for the Seminar of the Eurosystem and Latin American Central Banks, held in Frankfurt (March 2002) and Madrid (May 2002), respectively. The technical assistance of Jose Antonio Cuenca and Luís Molina is gratefully acknowledged. The paper has also benefited from comments made by Alicia García Herrero, Fernando Restoy, Heliodoro Temprano and Jose Viñals. The opinions expressed in the paper represent those of the authors and not necessarily those of their institution.
} 


\begin{abstract}
Over the last decade economic integration has advanced in both areas, and this has been seen as an opportunity for real convergence in Latin America and in the European periphery. But our approach emphasises that integration has to be supplemented by macroeconomic stability and structural reform. Focusing on these aspects, this work compares both experiences which, while very diverse in nature, depth and scope, may however offer through their differences and analogies interesting insights, especially for Latin America, as the degree of integration in Europe is much more advanced. The conclusions point to the need for a further effort in Latin America to achieve the fruits of reasonable policies, in order to compensate for the robust institutional underpinnings from which the European periphery has benefited. Thus, at the current juncture, as Latin America looks back with mixed feelings on the past decade, perseverance and determination in pursuing reforms are called for.
\end{abstract}




\section{Introduction}

Over the last decade economic integration has advanced in both Latin America and Europe. Integration, encompassing trade and capital openness, has been seen in Latin America and in the European periphery ${ }^{2}$ as a recipe for growth and real convergence with the more developed countries (more precisely with the United States for Latin America and the core European countries for the EU periphery). In the light of the European, and also the Latin American experience, this view is probably too simplistic (chart 1). Integration could indeed be considered as an important catalyst for real convergence, but on the other hand, the opening up of the trade and

CHART 1

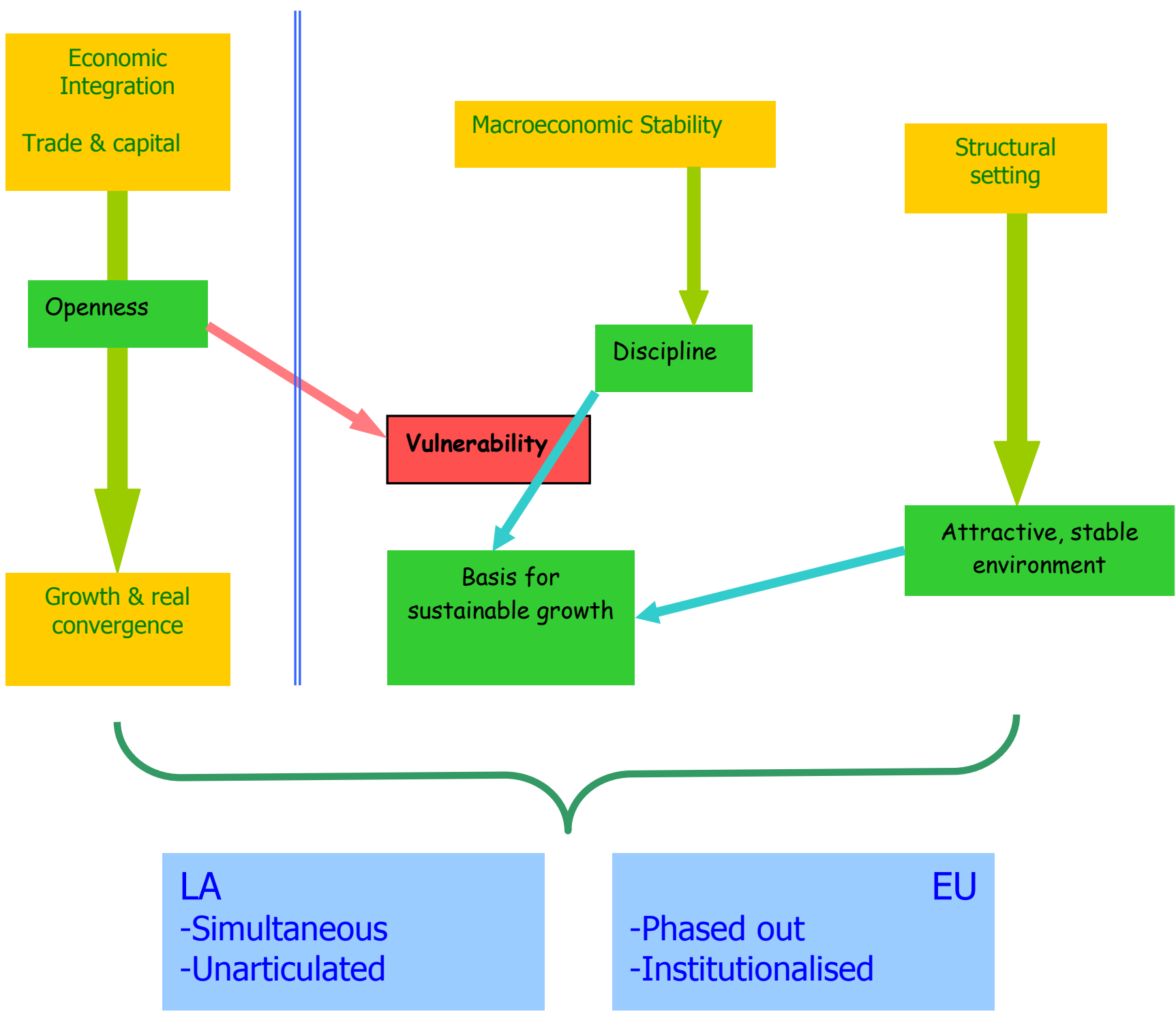

\footnotetext{
${ }^{2}$ The term "European periphery" is used here in an admittedly loose sense, meaning countries physically distant from the core, which in general (but not always) joined the EU at a later stage and lagged behind the core countries in terms of GDP per capita, nominal stability and capital endowment,
} 
capital account may entail an increase in exposure and therefore in the potential vulnerability of the economies in question. In any case, economic integration will only lead to real convergence when complemented with other elements that can be grouped under two headings: macroeconomic stability and an adequate structural setting. Macroeconomic stability requires a framework to maintain policy discipline, so as to counterbalance the potential increase in vulnerability and to allow for growth to be steady and sustainable. An adequate structural setting, defined by the observance and endurance of market principles, a consistent regulatory framework and the flexibility of the economy, shapes a stable environment to attract a continuous flow of capitals and to consolidate the functioning of the economy, thus contributing to create the conditions for sustainable growth.

The European integration process, in particular the experience of those peripheral countries in Europe, has attracted the interest of Latin America countries ${ }^{3}$. And in return, the potential and

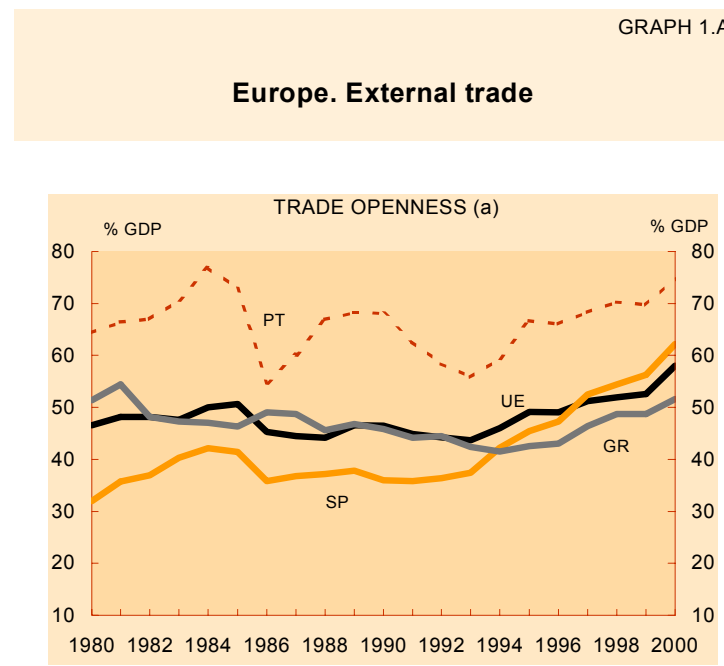

GRAPH 1.B

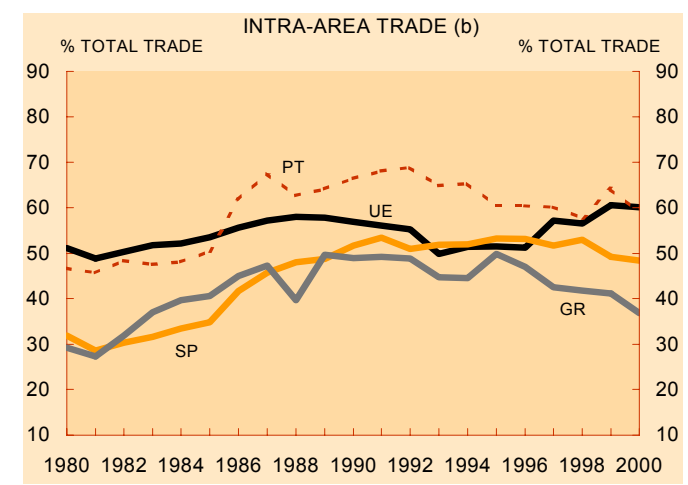

Source: WEFA.

(a) Sum of exports and imports as a percentage of GDP.

(b) Exports and imports to and from the block as a percentage of total exports and imports.
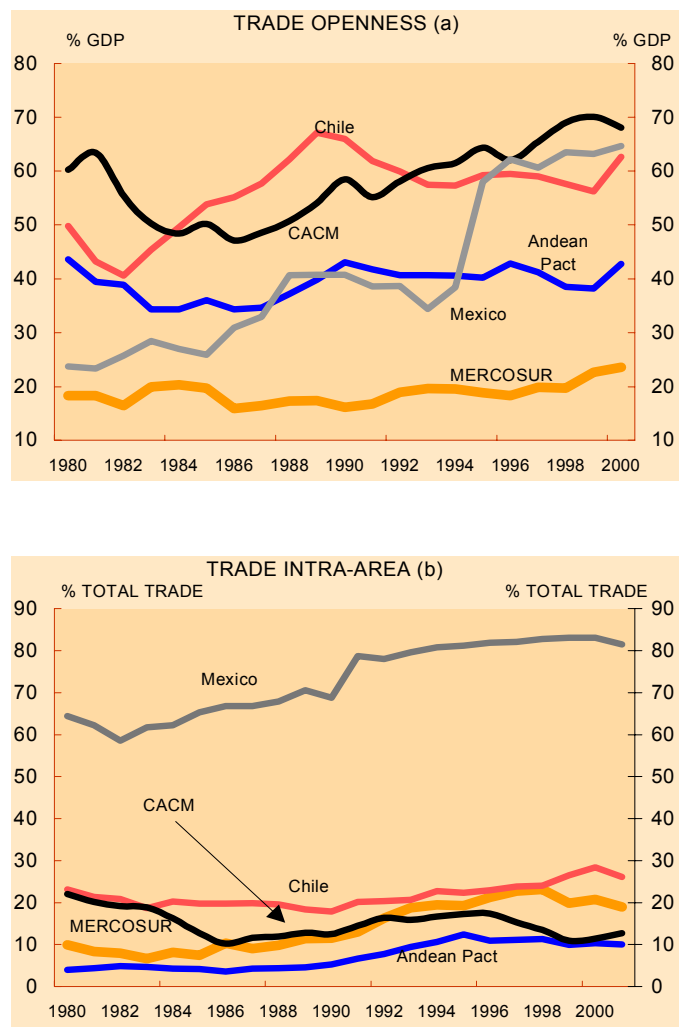

Latin America: external trade

Sources: own calculations and IMF.

(a) Sum of exports and imports as a percentage of GDP.

(b) Exports and imports to and from the block as a percentage of total exports. Mexico: exports to NAFTA. Chile: exports to Latin America.

\footnotetext{
${ }^{3}$ It could be argued, and indeed this paper stresses the point, that only North-South type integration processes exhibit some analogies to the periphery in Europe.
} 
modalities of Latin American integration are of increasing interest to Europe.

At first sight, both experiences are quite different in nature. For instance, the process in Latin America has advanced very rapidly on all the fronts considered (trade integration, macro stability and structural setting) since the late eighties, but it is devoid of sound institutional underpinnings. On the contrary, the European process has been lengthy and uneven, and it has tended to focus first on trade integration, then on macro stability -including exchange rate stability- and, more recently, on structural reforms. In the meantime a dense, imbricate and very robust institutional structure has been set in place which has sustained and reinforced the whole process.

Now that Europe has reached an important milestone in the integration process with the introduction of euro notes and coins, and that in Latin America there seem to be mixed feelings over the results of a decade of integration and reforms, a comparison of the respective processes would be particularly timely. Thus, this paper aims to study these experiences which, while very diverse in nature, depth and scope, may however offer through their differences and analogies interesting insights, especially for Latin America, as the degree of integration in Europe is much more advanced.

In order to frame our discussion, a summary comparison of the economic outcomes of both processes is displayed in the following graphs, focusing on the last two decades:

Integration (graphs 1): The outcome was quite similar in general for the new entrants in the EU in the eighties and for Latin America. Openness in the economy and capital flows increased substantially, and at much higher rates than the reference countries (EU as a whole, and the US/OECD, respectively) in both regions. Moreover, trade within the region has tended in general to increase as a share of total trade.

Macro-economic stability (graphs 2): The results are more diverse here. The process of nominal convergence did accelerate in the latter years in Europe, against the background of the EMU-required convergence criteria (inflation, deficit, debt, exchange rate stability, long-term interest rates). The reduction in macro imbalances, especially on the price stability and fiscal fronts, enjoyed a conclusive boost in the second half of the nineties. In Latin America the headway has been remarkable in price stability. In terms of fiscal discipline, after drastic stabilisation in the late eighties there has been some slippage, which has been corrected in the last couple of years. However, spreads on debt, which diminished dramatically in the European periphery, have followed an uneven trend in Latin America due to the sequence of financial crises in emerging markets. Also, the contrast in exchange rate stability reflects the process of locking of exchange rates prior to EMU, starting around 1995, and the exchange rate crises and drift towards floating regimes in Latin America.

Structural setting (graph 3): The European periphery made decisive progress over recent years in the structural framework of the economy as reflected in the competitiveness scoreboard displayed 

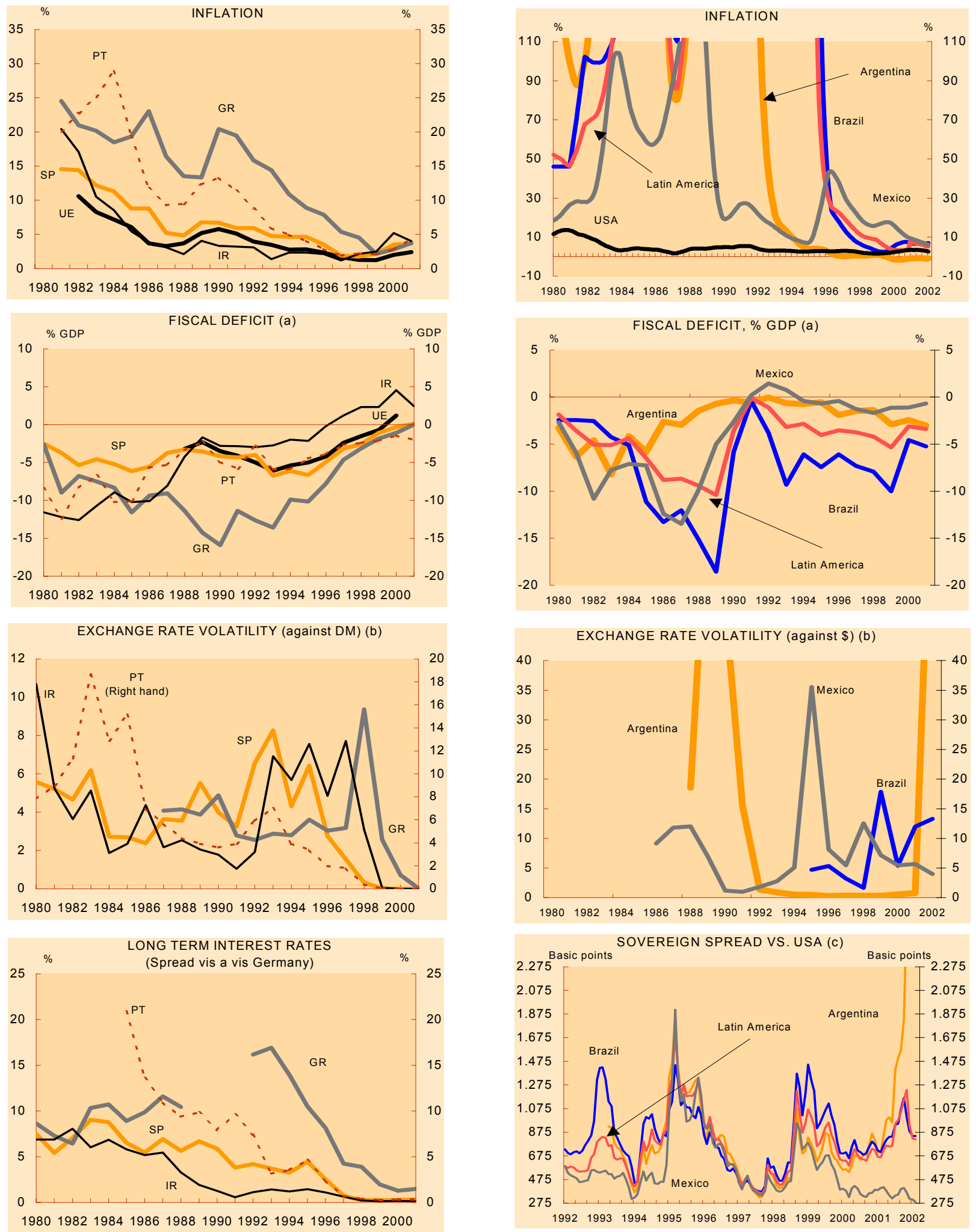

Source: Ameco, Eurostat, IFM and own calculations.

(a) General government

(b) Six month standard deviation of daily changes in exchange rate against $\mathrm{DM}$

Sources: own calculations, IMF and JP Morgan.

(a) Central government

(b) Six month standard deviation of daily changes in exchange rate against USD.

(c) EMBI spreads 


\section{Europe. Competitiveness scoreboard (a)}

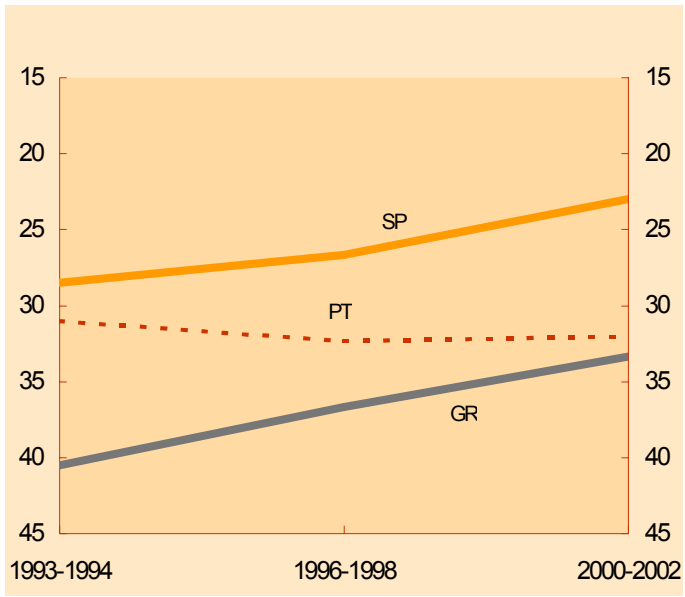

Fuente: IMD.

(a) Rank among 49 countries.

\section{Latin America: competitiveness scoreboard (a)}

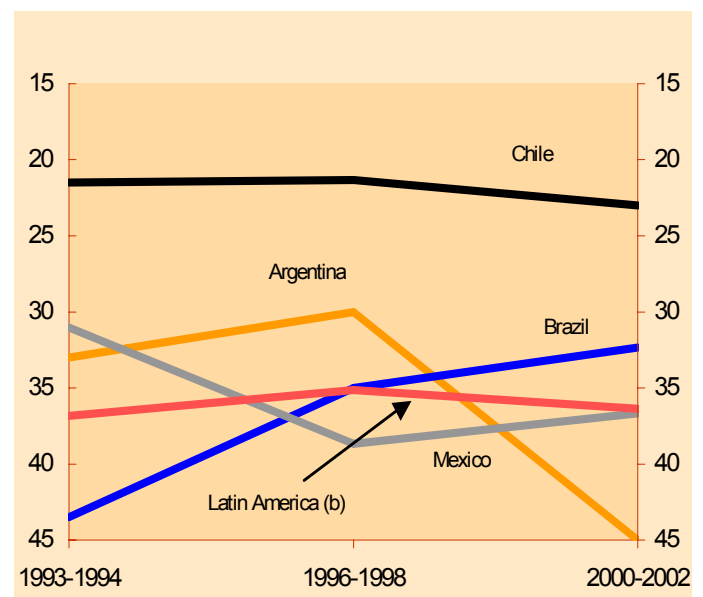

Source: IMD.

(a) Ranks among 49 countries

(b) Latin America comprises 6 countries (Argentina, Brazil, Mexico, and Colombia, Venezuela and Chile). Ranks weighted by PPPs.

in the figure ${ }^{4}$. The picture in Latin America is more diverse. The region as such has stalled but there have been advances in recent years in some countries.

Real convergence (graphs 4): The European periphery experience shows that the process of real convergence is not necessarily sustained. It accelerated around the entry dates due to the beneficial effects of the opening up of the economy, but it suffered setbacks (as a case in point, after the EMS crises). In the final years the process acquired fresh momentum in most countries. A similar lesson can be drawn from Latin America, which converged in the first half of the nineties but saw this process reversed in the second half, in the wake of financial crises.

The paper is organised as follows. In section 2 the European experience, focusing on the European periphery (and in particular the Spanish experience), is reviewed, stressing the main lessons and insights of the process. In section 3 a similar evaluation of the Latin American experience to date is made. Section 4 draws and develops the main conclusions of the analysis.

\footnotetext{
${ }^{4}$ The competitiveness scoreboard of the IMD attempts to capture in a synthetic indicator the relative competitiveness position (understood broadly as conditions for future growth) of the economy by focusing mainly on a set of structural indicators related to the business, government and productivity environment.
} 
Europe. Real convergence $($ OECD level $=100)$

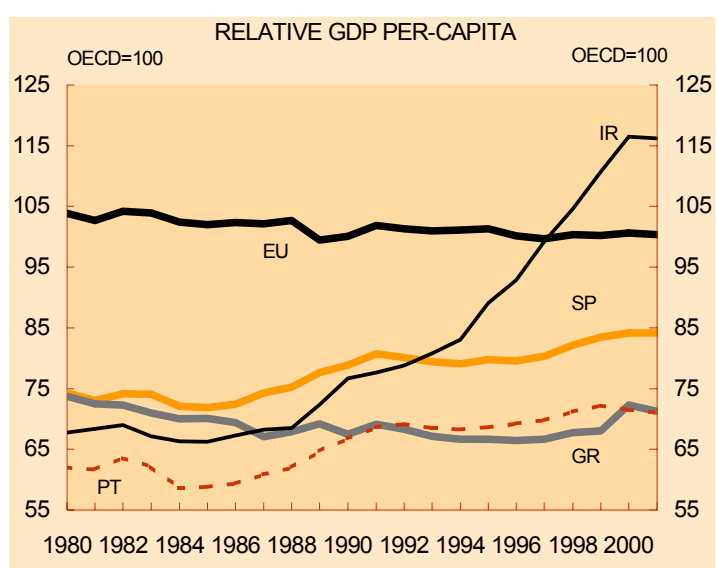

Sources: IMF and Banco de España. PPPs data.
Latin America: Real convergence (OECD level = 100)

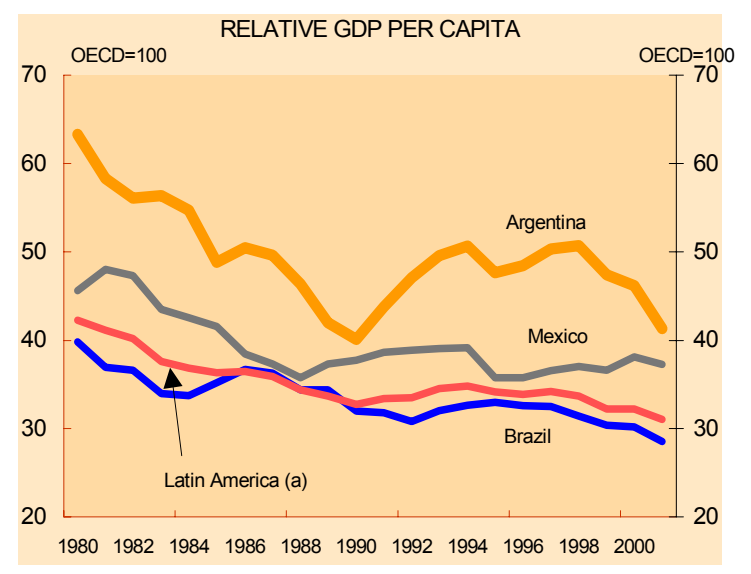

Sources: own calculations

(a) Comprises 16 Latin America countries. PPPs data.

\section{The European experience (with special reference to peripheral countries)}

\subsection{Comprehensive integration process}

The introduction of euro banknotes and coins on 1 January 2002 marked a milestone in the process of European monetary integration, in which the decisive step was taken three years earlier, in January 1999, with the creation of the euro and the establishment of a single monetary policy. The pace of integration has been uneven and the process very long. Periods of rapid advancement have been followed by periods of stagnation. Table $1^{5}$ shows the main steps to monetary union, which are described in Annex 1. In the early fifties, the will to create a common market was undoubtedly related to the legacy of two terrible world wars. It has taken more than forty years since the establishment of the European Economic Community to arrive at the present juncture and progress, characterised by a gradual deepening of economic and monetary cooperation, has not been free from crises. Having identified the main steps to monetary union, there appear to have been two key moments at which the process of integration was given special impetus. First, in the mid-eighties, when France decided to give priority to a stable exchange rate between the French franc and the Deutsche mark and hence to price stability, which was Germany's main policy objective. This followed a proposal for greater political co-operation and a deepening of integration, which led to the Delors Plan and the Single Market as the way forward for the European project. And second, in the mid-nineties, when the peripheral countries, after the severe EMS crises, made real headway in attaining the macroeconomic stability imposed as a condition for joining the euro area.

\footnotetext{
${ }^{5}$ From Bergeij, Berndsen and Jansen (2000)
} 
Table 1 - Gradual deepening of economic and monetary co-operation

\begin{tabular}{|c|c|c|c|}
\hline Year & Monetary Union & Single Market & New Members \\
\hline 1952 & & $\begin{array}{l}\text { European Coal and } \\
\text { Steel Community }\end{array}$ & \\
\hline 1958 & & $\begin{array}{l}\text { European Economic } \\
\text { Community }\end{array}$ & $\begin{array}{l}\text { Belgium } \\
\text { France } \\
\text { Germany } \\
\text { Italy } \\
\text { Luxembourg } \\
\text { Netherlands }\end{array}$ \\
\hline 1968 & & $\begin{array}{l}\text { Customs union for } \\
\text { industrial products }\end{array}$ & \\
\hline 1972 & 'Snake' agreement & & \\
\hline 1973 & & & $\begin{array}{l}\text { Denmark } \\
\text { Ireland } \\
\text { UK }\end{array}$ \\
\hline 1979 & $\begin{array}{l}\text { European Monetary } \\
\text { System }\end{array}$ & & \\
\hline 1981 & & & Greece \\
\hline 1986 & & & $\begin{array}{l}\text { Portugal } \\
\text { Spain }\end{array}$ \\
\hline 1990 & $\begin{array}{l}\text { EMU Stage One (capital- } \\
\text { account liberalisation) }\end{array}$ & & $\begin{array}{l}\text { East-German } \\
\text { Länder }\end{array}$ \\
\hline 1993 & & Common market & \\
\hline 1994 & $\begin{array}{l}\text { EMU Stage Two } \\
\text { (economic convergence }\end{array}$ & $\begin{array}{l}\text { European Economic } \\
\text { Area }\end{array}$ & \\
\hline 1995 & & & $\begin{array}{l}\text { Austria } \\
\text { Finland } \\
\text { Sweden }\end{array}$ \\
\hline 1999 & $\begin{array}{l}\text { EMU Stage Three } \\
\text { (monetary union) }\end{array}$ & & \\
\hline $20 ? ?$ & & & New entrants \\
\hline
\end{tabular}

Economic interdependence among EU Member States, as measured by the scale of intraEuropean trade, has grown considerably. The share of intra-EU trade as a percentage of total foreign trade rose from 40 per cent in the early 1960s to around 60 per cent in 2000 (see graph 1A). As regards capital markets, they were completely liberalised in June 1990 in the core countries and between 1992 and 1994 in the periphery. The process was gradual but not smooth, in that some countries, such as Spain (as will be explained later) underwent some reversals. Also, to put this ambitious economic integration program into effect, a full, complex, institutional and legal apparatus capable of creating binding legislation was set up. For this purpose, the EU created a number of truly European institutions, including the European Commission, the Council of Ministers, the European Parliament, the European Court of Justice and the European Central Bank. The competences of all these institutions increased as the integration process advanced. Table $2^{6}$ shows that the EU has become much more than an area of free trade and policy coordination. It also presents a list of policy responsibilities that have been transferred to central EU

\footnotetext{
${ }^{6}$ From Alesina and Wacziarg (1999)
} 
institutions and indicates the extent of EU involvement in each policy area (extensive, shared with national governments and limited). This table shows that European institutions have acquired responsibilities in a host of policy areas, including some that have little to do with fostering intra-EU trade or economic integration. On some issues, such as monetary policy and international trade policy, there has been a complete transfer of sovereignty and the supranational level has exclusive

Table 2 Policy responsibilities of the EU and their scope

\begin{tabular}{|c|c|c|c|}
\hline & Extensive & Shared & Limited \\
\hline \multicolumn{4}{|l|}{ Economic and social areas } \\
\hline Competition & & $x$ & \\
\hline Cultural policy & & & $x$ \\
\hline Regional policy & & $x$ & \\
\hline Employment and social policy & & $x$ & \\
\hline Enterprise policy & & $x$ & \\
\hline Equal opportunities & & $x$ & \\
\hline Industrial policy & & $x$ & \\
\hline Public health & & & $x$ \\
\hline Solidarity/welfare & & & $x$ \\
\hline Consumer policy & & $x$ & \\
\hline Monetary policy & $x$ & & \\
\hline Education, training and youth & & & $x$ \\
\hline Environment & & $x$ & \\
\hline Internal market & $x$ & & \\
\hline Research technology & & $x$ & \\
\hline Trans European networks/mobility & & & $x$ \\
\hline \multicolumn{4}{|l|}{ Sectoral policies } \\
\hline Agriculture & $x$ & & \\
\hline Fisheries & $x$ & & \\
\hline Transportation & & $x$ & \\
\hline Information and telecommunications & & $x$ & \\
\hline Audiovisual policy & & & $x$ \\
\hline Energy & & $x$ & \\
\hline \multicolumn{4}{|l|}{ External policies } \\
\hline Common foreign and security policy & & & $x$ \\
\hline Development policy & & $x$ & \\
\hline Humanitarian aid & & $x$ & \\
\hline Common trade policy & $x$ & & \\
\hline
\end{tabular}


competence. It should also be pointed out that on many occasions the supranational nature of Community law has entailed tensions between the Member States, and conflicts within the Community institutions. The start of Stage Three of EMU (Economic and Monetary Union) in 1999 could be considered as the most important step in the process of sovereignty transfer. This was the culmination of a process embarked upon in 1989 with the approval of the Delors Report at the Madrid European Summit.

\subsection{Macroeconomic stability}

EMU has been designed as an area of macroeconomic stability, in the sense that the entry conditions and the institutional set-up are geared towards avoiding macroeconomic imbalances. In this respect the advances made in the second half of the nineties by the peripheral countries, traditionally characterised by weak fundamentals, have been especially relevant. In these countries the consequences of integration have been experienced more intensely and the related transformations have been particularly rapid and far-reaching.

When the peripheral countries embarked on the process of European integration, their economic model was not unequivocally based on openness, free markets and macroeconomic stability, the basic pillars of integration. Internal resistance to economic liberalisation and more flexible markets was accompanied by scant appreciation of the inherent value of macroeconomic stability. Moreover, in the case of Spain (the largest of the peripheral countries), which only gradually emerged from a state of autarky from the sixties onwards, democratic consolidation, the need to improve the welfare state, industrial restructuring and political devolution led to a significant increase in public spending, which was not matched by a similar increase in tax revenue, despite the fiscal reform that came into force in 1978. Additionally, the social unrest following the change in political regime led to sizeable wage rises. Supply rigidities and demand pressures also contributed to significant increases in inflation.

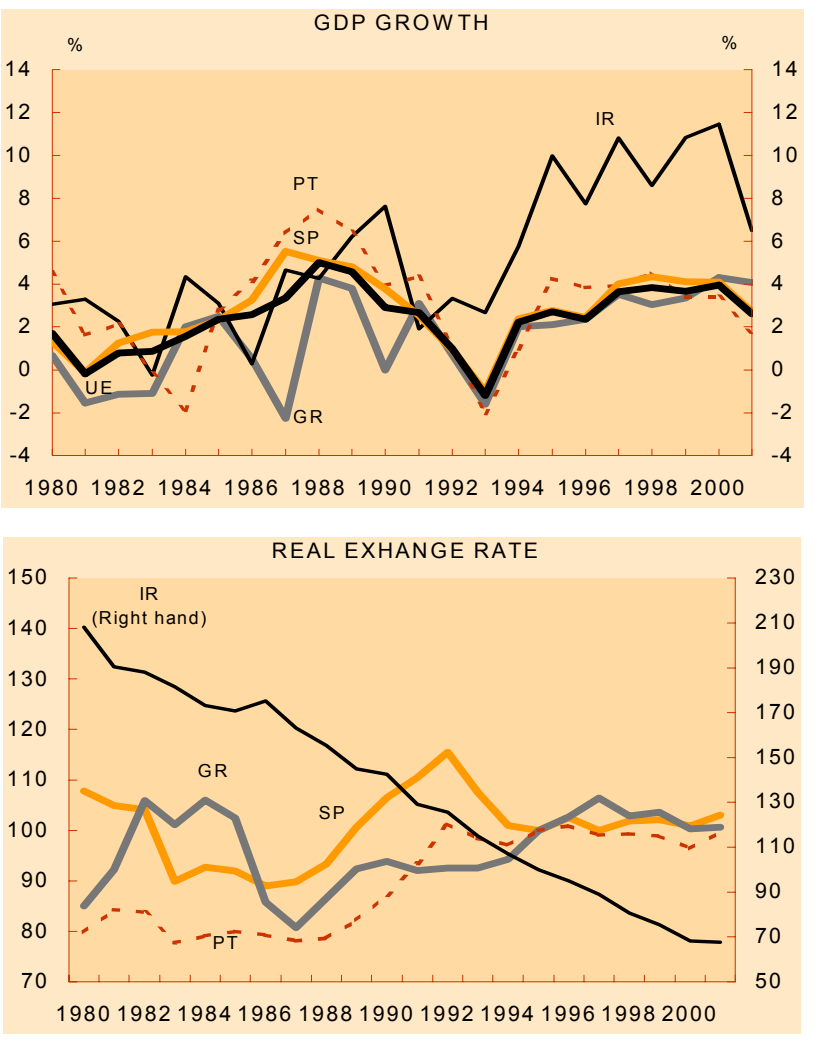

Sources: Ameco, Eurostat and IMF. 
The change of course required in the peripheral countries to adopt the patterns of behaviour imposed by European integration had to be achieved in a very demanding environment. This was due to the intensity of integration and to its timing: the peripheral countries joined the EU at a time the integration process was accelerating, in particular in the monetary sphere. The EMU project imposed some particularly strict requirements, even for economies with a greater tradition of stability. Spain, like the other peripheral countries, not only had to join this race from a particularly distant starting point because of its particular situation (explained in the paragraph above); it also had to pursue a moving target that became more demanding the closer it came. The road was an arduous one and Spain was sometimes moving in the wrong direction. Such a loss of ground was particularly serious when an unbalanced policy mix was applied as a result of expansionary procyclical budgets that contributed to fostering excessive capital inflows, putting pressure on the current account and over-burdening monetary policy with tasks it could not achieve on its own. Two periods from the recent past of the Spanish economy illustrate this point:

1. -EU entry (1986). The gradual dismantling of exchange controls and the unbalanced policy-mix led to a vicious circle. Capital attracted by Spain's growth potential and the high prevailing interest rates fuelled excessive monetary growth. The attempts to sterilise it, in the face of inflationary risks, prompted fresh rises in interest rates, which in turn attracted more foreign capital, and so on. This self-sustaining process was particularly virulent in 1987. The authorities raised interest rates to hitherto unknown levels, but this was not enough to contain either the growth of the monetary aggregate (the demand for which was, moreover, prone to marked instability at that time owing to financial innovation) or inflationary pressures, and it merely refuelled capital inflows and the strength of the exchange rate. Finally, the authorities were obliged to lower interest rates and reintroduce capital controls, which, contrary to traditional ones, sought to deter the short-term capital inflows that were distorting monetary policy implementation. Had fiscal policy been tighter, monetary policy could have been eased somewhat, with an alleviation of exchange rate tensions. EU entry therefore exposed the unsustainability of the macroeconomic strategy of the mideighties.

2. -The ERM crisis (1992-1993). In 1992 the Spanish economy began to show signs of sluggishness after an exceptionally long-lasting and intense upturn. At the same time, February 1992 saw the dismantling of the last exchange controls on both capital inflows and outflows, eleven months ahead of schedule. The ERM crisis was the outcome of a combination of several factors: the doubts about the future of EMU which arose in the wake of the negative outcome of the Danish referendum in June 1992 and were exacerbated in the run-up to the French referendum in September that same year; the loss of competitiveness suffered in the countries where nominal convergence had not advanced enough (see graph 5), after more than five years without realignments of the parities in the ERM (the so-called "hard ERM", which was wrongly seen at the time as a quasi-monetary union); the outcome of German unification, which first induced a prolongation of the cyclical upswing in Germany, whereas the rest of Europe was undergoing a sharp slowdown, and second, an unbalanced policy mix in Germany; and, finally, the numerous contagion effects between countries prompted the onset of the crisis and fuelled its persistence. The crisis caused the withdrawal in late 1992 of sterling and the lira from the ERM, 
and the abandonment by the Swedish, Norwegian and Finnish currencies of their unilateral links with the ECU. Numerous realignments also ensued, including the devaluations of the peseta in September and November 1992 and April 1993 ${ }^{7}$. However, market doubts about the preparedness and ability of EU countries' authorities to raise interest rates in defence of exchange rates in cases where such policies might clash with the requirements of the domestic economy led to new pressures within the ERM. As a result, in August 1993, the finance ministers and central bank governors of the Member States decided to widen temporarily the fluctuation bands within the exchange rate mechanism of the ERM to 15 per cent, while maintaining the existing central rates. The widening of the bands contributed to restoring exchange rate stability in the ERM, by lessening the focus for speculative attacks. The size of the macroeconomic imbalances was the main cause of the peseta devaluation: the public deficit was huge and the trade balance deficit mirrored the economy's lack of competitiveness. The devaluations addressed the latter problem and boosted activity, but the consequences of the whole episode in terms of capital stock and unemployment were very significant.

In subsequent years the discipline imposed by the requirements to move forward with European integration, reflected in the convergence criteria ${ }^{8}$ and the lessons drawn from previous periods, resulted in a more balanced policy mix in Spain, which enabled economic recovery to take place without inflationary pressures. The confidence of economic agents in the resolve to control inflation, related among other factors to the enactment of the independence of the Banco de España in 1994 and the subsequent change in the monetary policy strategy towards inflation targeting, was crucial in this respect, leading to a moderation of inflation expectations and wage demands. It should be noted that the peripheral countries had strong incentives to achieve and maintain nominal stability. As has been pointed out above, their economic progress has traditionally been constrained by their propensity for instability (even after EU accession), which had periodically induced crises and reversals. For the same reason, these were the countries that had most to gain from the low and stable inflation rates that EMU was supposed to bring, whereas the core countries, which had been able to achieve price stability by themselves, had fewer incentives from this viewpoint (although there were other incentives for EMU in their case, related in particular to the deepening of the Single Market) $)^{9}$. Another interesting aspect of nominal convergence in EMU was the role played by emulation in creating incentives for appropriate policies in peripheral countries. The key role played by German monetary policy in consolidating price stability as the primary goal of European monetary policies in the run-up to EMU has been mentioned above. Emulation also played a role in terms of "peer-pressure" among European countries, in the sense that the costs of indiscipline rose perceptibly as an increasing number of countries achieved nominal stability. In the run-up to EMU, the political embarrassment of being "left behind" also played a positive role for some peripheral countries.

\footnotetext{
${ }^{7}$ The peseta was devalued again in March 1995, but in a rather different context characterised by the aftermath of the Mexican crises and the ensuing dollar weakness.

${ }^{8}$ In Banco de España (1997) there is a detailed explanation of the convergence criteria.

${ }^{9}$ It is interesting to note in this regard that polls on popular support for EMU in the run-up to the euro systematically showed a positive correlation between such support and historical inflation rates.
} 


\subsection{Structural setting}

Despite the fact that the market integration process made it increasingly necessary to advance in the structural setting, only in recent years has the latter improved significantly in the euro area countries and, in particular, in the peripheral ones. This was due to a lack of liberalisation and the high degree of rigidities previously characterising those countries. The willingness to ensure competitive conditions within the common market, to harmonise national law to ensure its proper functioning and the creation of a European Social Fund were already proposed as objectives in the Treaty of Rome (1958). However, progress in these areas has been very slow, despite the political will reflected in the White Paper on the internal market, presented by the Commission in 1985, the Single European Act which came into force in 1987 and, finally, the Treaty on European Union signed in Maastricht in 1992. The recent advance in enhancing the structural setting is related to Monetary Union. At the same time that Monetary Union has entailed the application of a common monetary policy for all the countries that have adopted the euro, European economic integration has given rise to greater co-ordination of the other strands of economic policy that remain under national sovereignty and have become the main tools for nominal convergence. This co-ordination has taken the form of public adoption of fiscal policy and structural reform objectives by each Member State and the supervision of their fulfillment through joint monitoring of the progress made. The main instrument of co-ordination is the so-called Broad Economic Policy Guidelines (BEPG). These are established annually and supplemented, in the fiscal sphere, by the Excessive Deficit Procedure as part of the Stability and Growth Pact, and by the progress reports on reforms in the markets for goods, labour and capital. In this sense, many measures that have been taken in Spain and other peripheral countries to improve the competitive environment have been introduced in line with the schedule laid down by Community directives. This means that, for Spain and for other European countries, becoming a EU member has prompted the introduction of many liberalising measures that might otherwise have been postponed. Additionally, references to the need to improve competition in order to benefit from the integration process was used from time to time by some governments to seek the social consensus to implement structural measures. The following paragraphs review the progress made in relation to the structural setting. First, the progress made in the context of the euro area on structural reform policies is assessed. And second, drawing on a number of indicators, the advances in aspects related to social enhancement are highlighted.

\section{Competition in product markets ${ }^{10}$}

For the Single Market to be more than just a customs union, it has been necessary not only to dismantle physical obstacles to the free circulation of goods but also technical and fiscal barriers, aligning the laws of the member countries, liberalising markets for services and opening up public markets. Progress on these aspects has been slow. Important, in this respect, have been the initiatives aimed at enhancing product market integration included in the successive action plans adopted in recent years by the Council, such as the 1997 Single Market Action Plan, which urged

\footnotetext{
${ }^{10}$ Based on OECD (2001)
} 
improvements in the rules governing public procurement and the setting of technical standards. This stressed that state aid and differences in taxation create distortions and are potentially detrimental to cross-border trade in goods and services. The Helsinki European Council of December 1999 endorsed a new Internal Market Strategy, which outlined key objectives for the next five years and set up mechanisms for tracking and updating target actions. The 2000 Council review of this new strategy showed that, notwithstanding substantial progress in some areas, overall a lot remained to be done. The introduction of the euro as a common currency for the twelve euro area countries will boost competition in the euro area by smoothing trade and improving market transparency.

\section{Financial markets}

European financial markets are far more integrated than a decade ago. The advent of the euro has effectively created a single money market. However, markets for longer-term finance, including venture capital, remain fragmented, notwithstanding the proliferation of pan-European stock indices and more or less successful joint undertakings between various stock exchanges. Merger and acquisition activity in the banking sector has intensified, but largely within rather than across borders. At the same time, accounting standards, listing and prospectus requirements, as well as rules governing occupational pension funds and collateral, continue to differ widely across Member States, to the detriment of firms' ability to raise funds or expand EU-wide. On top of the various Banking Directives in the last decades, a Financial Services Action Plan was launched in 1999 to give financial market integration renewed impetus, which the EU Council in Lisbon pledged to implement in full by 2005 . Some progress has been achieved. For example, agreement has been reached on a European company statute, which will allow a firm with subsidiaries in several Member States to operate under a single legal regime. Given the pace of transformation of the financial landscape and the time it takes for EU directives to be agreed by the Council and then implemented, there is a need to accelerate reforms in this area. Against this background, a Committee of "Wise Men" issued last year a set of useful recommendations, the Lamfalussy Report, to improve the EU securities markets' regulatory framework ${ }^{11}$.

\section{Labour market}

Headway in this area has been prompted not so much by Community law, as in the case of goods and services and the financial markets, but rather by the conviction of member countries as to the positive effects that improvements in this field have on price determination in the economy, employment and its growth potential. In particular, in most euro area countries, the employment rate remains far below the level in the United States or in the Nordic countries, suggesting that there is room aplenty to lift potential output and growth. The vigorous job creation witnessed in the last few years partly reflects the measures taken by Member States during the 1990s to lower the cost of labour and/or to raise real wage flexibility. Sustained wage moderation, helped by cuts in social security contributions and taxes, played an important role. Spain is a clear example in this

\footnotetext{
${ }^{11}$ See Committee of Wise Men (2001)
} 
respect. Labour markets have also tended to become more flexible, as witnessed by the large contribution of part-time and temporary employment to overall job creation. Notwithstanding, policy initiatives on the benefit side are still insufficient in some countries. It is also necessary to improve incentives to take up work, via the review and, where appropriate, reform of benefit, tax and training systems.

\section{Human \& social capital enhancement}

There are few doubts that the accumulation of social capital (understood as investment in education, health and infrastructure) is not only a catalyst for social cohesion but also a basis for sustained growth and convergence. The improvements in these fields in Spain and other peripheral countries have been impressive. In recent decades the advances in gross fixed capital formation and social expenditure, including spending on health and education ${ }^{12}$, have been notable (see graph 6). In the peripheral countries, much of this progress was made possible by the fiscal reforms adopted and the consequent widening of tax bases. All this enabled advances in terms of social capital enhancement and income distribution. Nonetheless, Spain still has a long way to go when comparing with EU levels. It is true, again, that the integration process has helped social enhancement in Spain and in other peripheral countries due to the basic EU budget objective of reinforcing the economic and social cohesion of the Member States through transfers to the less developed countries and regions. Notable among the funds received are the European Regional Development Fund, aimed at developing infrastructures; the European Social Fund, for job training and guidance and for services and technical advice related to job creation; and the

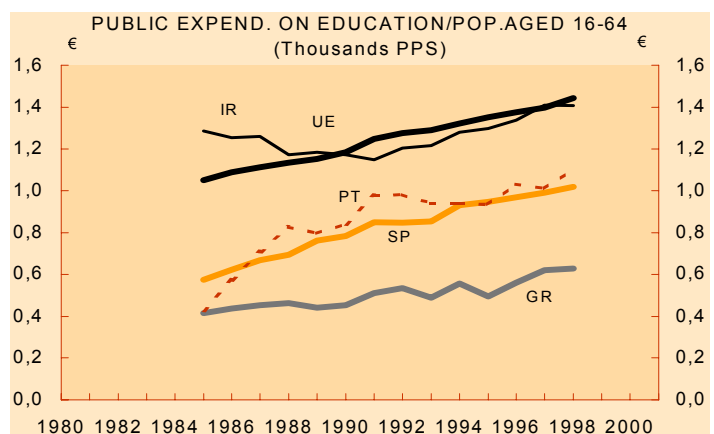

19801982198419861988199019921994199619982000

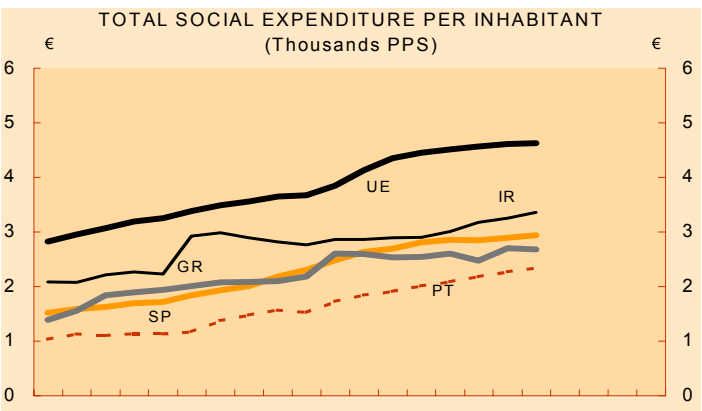

19801982198419861988199019921994199619982000

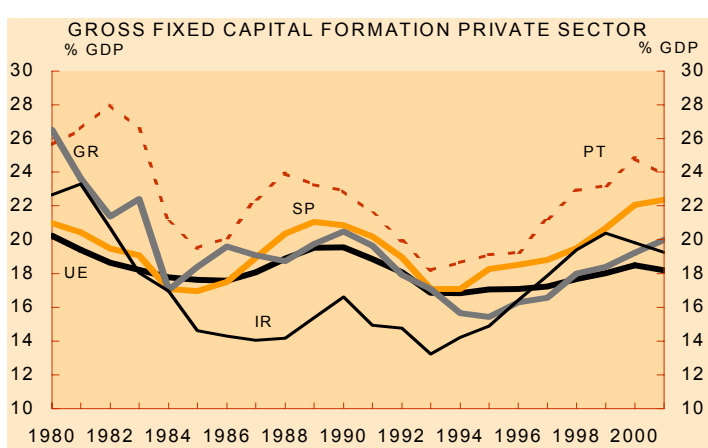

19801982198419861988199019921994199619982000 GROSS FIXED CAPITAL FORMATION GOVERNMENT

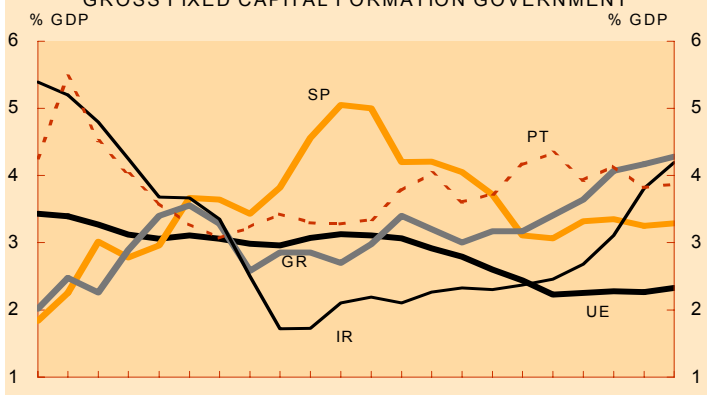

$1980198219841986198819901992199419961998 \quad 2000$

Sources: Eurostat, Ameco, FUNCAS, OCDE and Banco de España.

\footnotetext{
${ }^{12}$ In Banco de España (2001) there is an explanation about the methodology and sources used to obtain these indicators.
} 
Cohesion Fund, for environmental and transport infrastructure projects. These funds accounted for around $5 \%$ of gross fixed capital investment on average in the nineties for the peripheral countries.

Despite the progress made in Europe in relation to the structural setting, there is some way to go still for both Spain and the euro area in general. In particular, there are two reasons behind the need for further advances in structural reforms in EMU. The first is the lack of economic dynamism in the euro area as reflected in relatively low growth rates of production and productivity, and a comparatively low level of innovation, in particular when compared with the US. The European model is characterised by a high degree of social cohesion and equality but is far from optimal in terms of flexibility and the capacity for innovation. The second reason is the need to improve the ability of the euro area economy to adjust to shocks. Adjustment processes in product and labour markets in Europe are traditionally very slow and prolonged. The need for flexibility is particularly crucial following the adoption of a single currency, since adjustment via the exchange rate is no longer possible.

\subsection{Real convergence.}

As a result of the sustained pursuit of stabilityoriented macroeconomic policies, together with determined structural reform measures to increase market flexibility, Spain and the peripheral countries in general have been able to reduce inflation rates and inflation expectations and, at the same time, to make progress in real convergence. Real and nominal convergence should be seen as complementary and should be pursued in parallel. In fact, the Spanish economy regained the path of real convergence towards European levels of welfare following EU entry, which ended a period of 10 years of decline in its
Real convergence

$($ EU level $=100)$

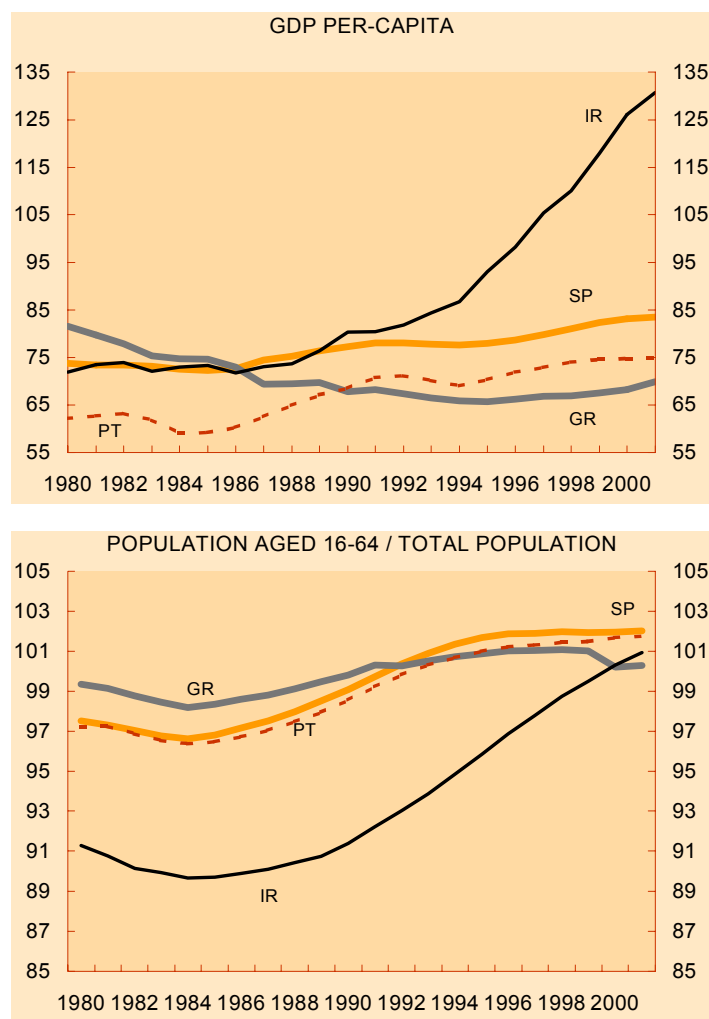

EMPLOYMENT RATE
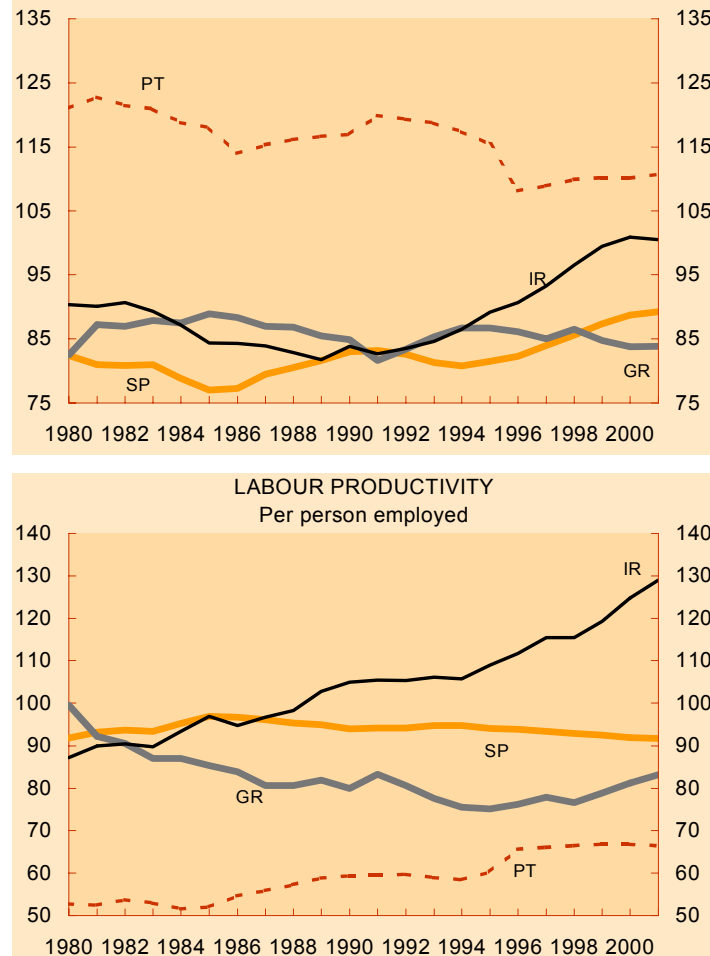

Sources: Ameco and Banco de España. 
relative welfare. As can be seen in graph $7^{13}$, the peripheral EU countries in general tended to catch up in terms of GDP per capita with the EU average over the last 20 years, although the process was uneven, with frequent slippage, and the final results differ considerably across countries. The shift in the relative position of Ireland in the 90 s (from GDP per capita $25 \%$ below the EU average to more than $25 \%$ above) is particularly remarkable. Close examination of this convergence process in the case of Spain shows that, in recent years, the path of convergence towards European levels of welfare has been regained as a consequence of the intensity of job creation, while Spain has continued to lag behind in terms of labour productivity, mainly because of its relatively modest total factor productivity (TFP) growth. This fact illustrates the need, already referred to in the structural setting section, to increase the stock of physical, technological and human capital. This need exists in all European countries, but especially in the peripheral ones that have yet to catch up.

Another way to view the real convergence process is in terms of competitiveness, defined broadly, as the International Institute for Management Development (IMD) does. Competitiveness is the ability of a nation to create an environment conducive to sustained value added creation. According to this information, Portugal and, especially, Greece and Spain have advanced notably in recent years on the world competitiveness scoreboard. In particular, between 1996-1998 and 2000-2002, Spain has moved from 27th position to 23rd, Greece from 37th to 32nd and Portugal has remained at $32 \mathrm{nd}$, although these rankings are still far from the EU average. As a conclusion to the foregoing paragraphs, the macroeconomic stability and reforms arising from the EU integration process have been extraordinarily beneficial to the Spanish economy and to other peripheral countries, and have been reflected in improvements in real convergence. However, convergence was not an automatic result of integration. Although integration and the accompanying institutional setting were extremely useful, nominal and real convergence targets were only achieved when the right policies were adopted and implemented.

\section{Evaluation of the process in Latin America}

The recent process of integration in Latin America cannot be disentangled from the broad policy regime shift that has taken place during the late eighties. As in the case of the European periphery, the diversity of experiences of Latin America countries warrants a note of caution. A conscious effort has been made to underline the common traits, without much specific reference to particular cases; therefore, the generalisations made in this section should be taken as corresponding to very broad general trends in the region.

\subsection{Limited integration}

After the debt crises that erupted in 1982 and some years of economic turmoil in the aftermath, little by little the need for a new economic model took hold in the policymakers of the region. By the end of the eighties, the programmes of economic stabilisation and reform spread through the

\footnotetext{
${ }^{13}$ See footnote 12
} 
region in different waves, and they fostered the process of economic integration, which remained basically regional in the sphere of trade, but which was global in the capital markets.

Regarding trade, back in the sixties there were several initiatives, such as LAFTA (ALALC in Spanish), to increase trade integration, but they did not achieve any relevant results. The nineties, on the contrary, saw a great boost to the process of trade integration (as table 3 illustrates). Especially relevant were the founding of Mercosur (1991) and the North American Free Trade Area -NAFTA- (1994). The reshuffling of the Andean Pact in 1991, the CARICOMs Agreements among Caribbean countries and, finally, the multiplicity of bilateral or ad hoc pacts (more than twenty), to which Chile was one of the main subscribers, complete the broad picture of regional integration agreements. Deeper trade integration brought about an overall cut in tariffs (from $41.6 \%$ in the eighties to around $10 \%$ now), non-tariff restrictions (from $37.6 \%$ to just $6 \%$ of imports) and exports subsidies, which has favored a substantial increase in trade and openness in the region, as observed in graph 1B. Latin America has in fact become the most dynamic export region after East Asia in the nineties, with annual growth of more than $10 \%$. However, the impulse concentrated to a significant extent in Mexico (+20\%) and extended to other Central American countries as a result of NAFTA and "maquiladora" (offshore processing and re-export) agreements.

Note that two types of integration processes currently coexist in the region, whose ambition and scope differ: a South-South model (represented prominently by Mercosur) and a North-South model (e.g NAFTA). Mercosur aimed at a deeper degree of integration and was devised as a common market (free trade area plus common external tariff), where there have been attempts at economic policy co-ordination, such as the establishment of a convergence policy at the Florianopolis Summit in 2000. However, even on the trade front, the institutional framework remains loose, since there is not yet any effective institution to settle trade disputes, or a common position on trade to deal with other partners; moreover, economic divergences, the differences in the evolution of exchange rates and the lack of a macroeconomic anchor within the system are probably additional hurdles to further integration. The ambition of Mercosur requires more intense and complex political negotiation among sovereign states. NAFTA is less ambitious in that it is limited to a free trade area, but it has a particular interest since it is one of the few examples of a genuinely free trade area between industrial and emerging countries (North-South integration). This has boosted manufacturing exchanges in the form of "maquiladoras" between US and Mexico, which are behind the increase in intra-area trade seen in graph $1 \mathrm{~B}$.

The quest for wider, if not deeper, integration retains its momentum in the sphere of trade, as shown by the commitment to a Free Trade Area for the Americas (FTAA), agreed in 1995 and strengthened at the last Americas Summit in April 2001, with the undertaking that the FTAA become effective in 2005. However, very different views about the geometry, depth and nature of integration seem to persist in the region. 


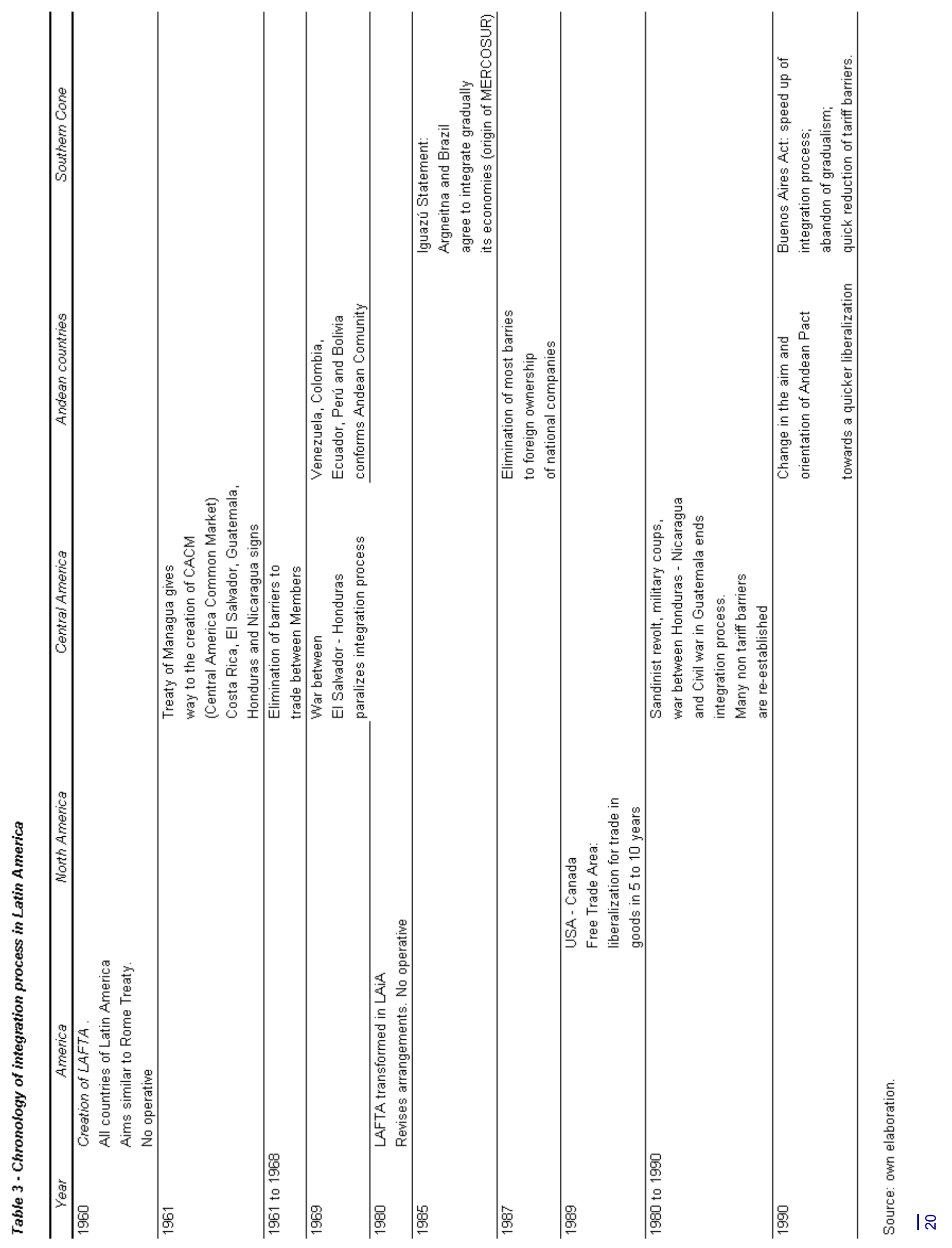




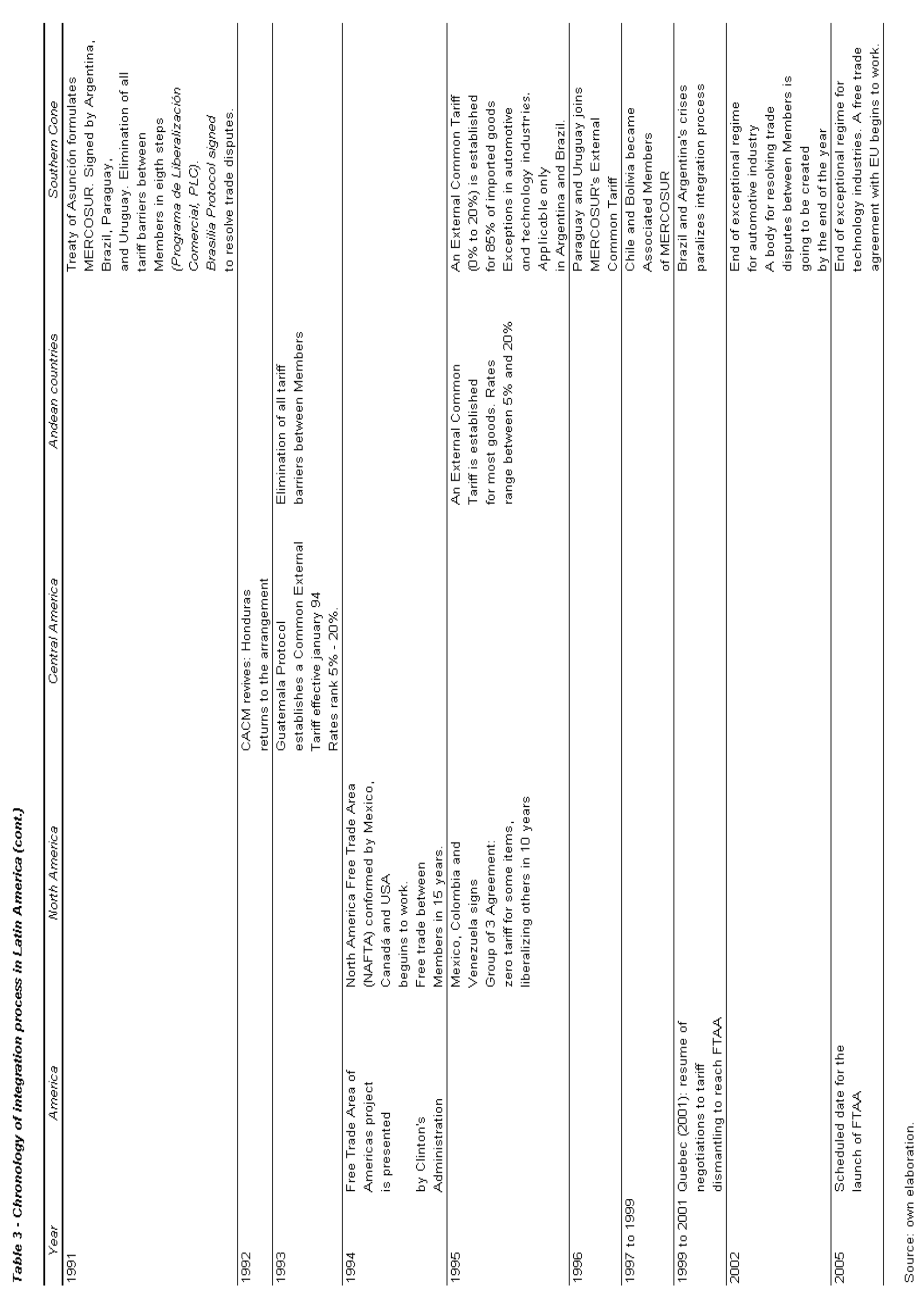



profound process of integration into the global capital markets. The restructuring of debt through the Brady Plan (1989) marked a turnaround, further impelled by the processes of capital account liberalisation which the reform programmes pursued $^{14}$ at different speeds and depths. The dramatic increase in capital flows to the region observed in graph 8 meant a substantial change in structure. Portfolio flows (equity and bonds) became prominent in the early years, and foreign direct investment (FDI) surged strongly afterwards helped by the parallel process of privatisation (at the expense of official flows and syndicated bank loans). The magnitude of flows and, to some extent, the change in their composition (portfolio flows are intrinsically volatile) contributed, among other factors reviewed below, to increasing the vulnerability of LA countries, heavily relying on external financing. This fuelled a lively debate in the region on the optimal sequence of capital account liberalisation. There is some evidence that to fully reap the benefits of liberalisation and to mitigate the vulnerability of volatile capital flows, it is essential to build up first a sound and deep domestic financial system. Another debatable point is whether stabilisation plans which promise large short-term gains but are surrounded by medium-term uncertainties intrinsically favour excessive inflows, followed by sudden stops or reversals, and whether the current global financial architecture creates some perverse incentives which might reinforce these problems.

\section{Net capital flows to Latin America}
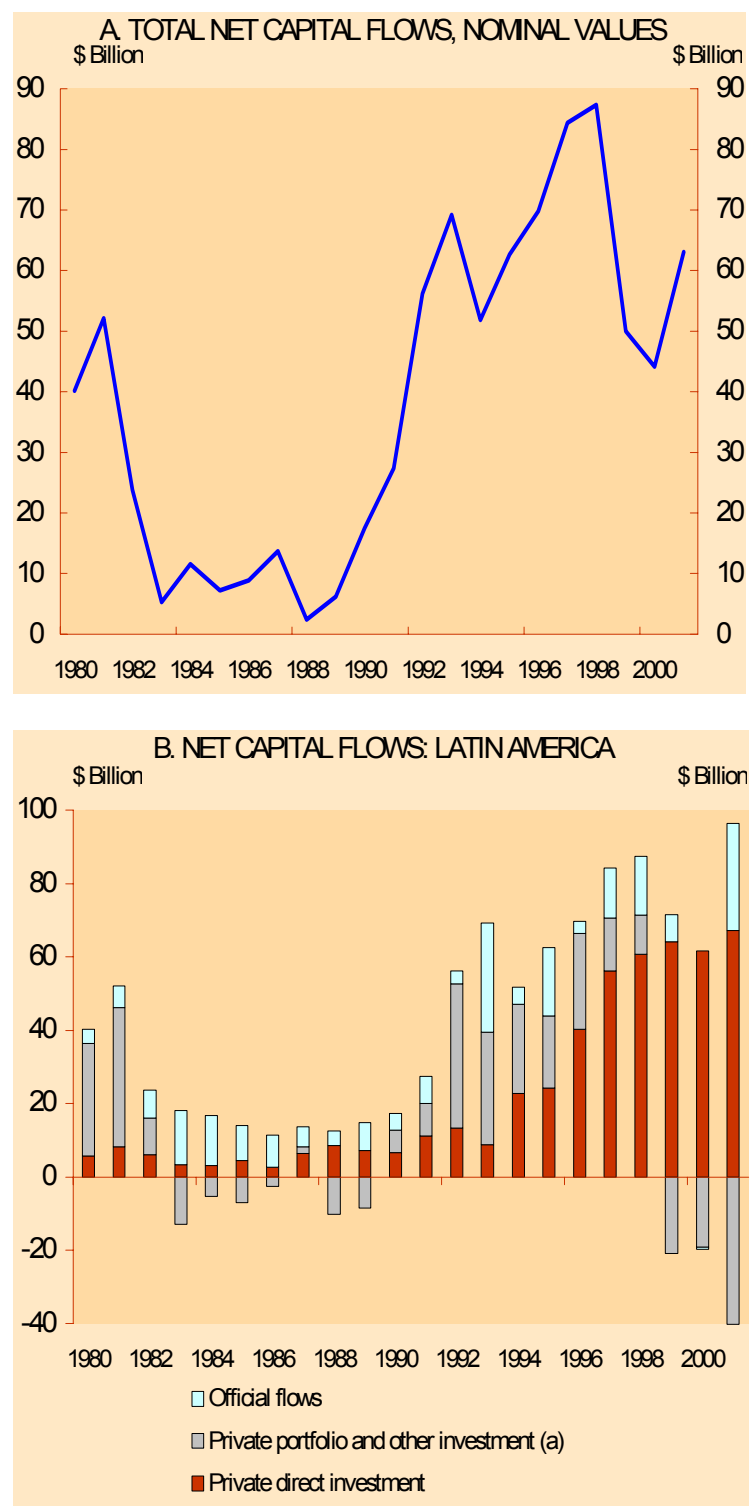

Sources: IMF WEO database.

(a) Indudes loans.

\footnotetext{
${ }^{14}$ Mexico or Argentina went very far and fast in liberalisation. Brazil and Colombia have followed a more paused and limited approach, while Chile, which opted for this same approach, has recently accelerated the process of financial liberalisation
} 


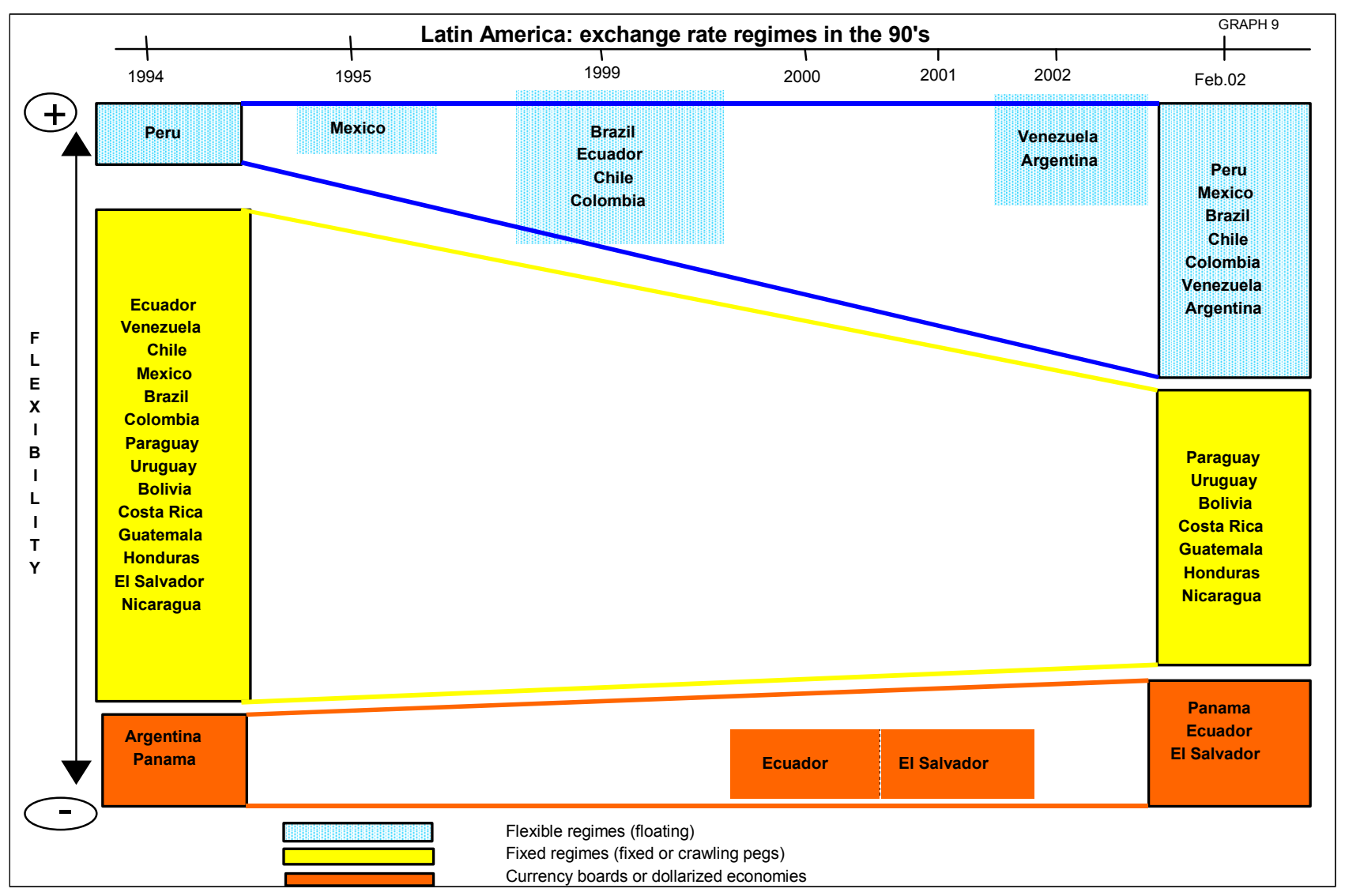

Source: own elaboration.

\subsection{Macroeconomic stability}

The programmes of reform and stabilisation applied in the nineties contributed to a substantial improvement in the macroeconomic environment in most of the region, as observed in graph 2B. Advances in price stability have been particularly notable: most countries are enjoying one-digit inflation rates, after many years of high inflation. As displayed in graph 9, in the initial phase of the process price stabilisation was in most cases achieved through the pegging of exchange rates, but since the second half of the decade all pegs have been abandoned (and the only fixers are those which adopted dollarisation of the economy: El Salvador, Ecuador). Among floaters, there has been a move towards the adoption of direct inflation targeting regimes and more autonomous central banks which may be considered, despite the difficulties, rather successful.

Fiscal performance is more difficult to judge, due to the complete overhaul of fiscal accounts in the last decade. In any case, there is an increasing awareness that fiscal discipline is necessary to improve overall stability, although some hurdles to expenditure control remain, mostly in expansions. Despite the efforts made, fiscal policy has traditionally shown a pro-cyclical pattern (see graph 10): when the economy grows, increased fiscal receipts and access to external financing stimulate government expenditure, thus feeding additional growth and inflation; in bad times, lower tax receipts and greater difficulties for raising financing on international markets force budgetary retrenchment, in particular expenditure cuts, - which causes additional economic 
contraction. This pro-cyclical bias is an additional source of volatility for macroeconomic policies, but experience shows that fiscal discipline can ultimately stimulate growth potential through a reduction of the risk premium in the economy.

These advances in monetary and fiscal stability did not preclude financial instability. A major obstacle is that high levels of debt and interest rates for public finances impose, in general, a cumbersome external debt burden for the economy. The vulnerabilities associated with these burdens are heightened, respectively, by the narrow tax base and the limited openness of economies, which make debt service a heavy drag on the economy, as compared, for instance, to Asian countries (see graph 11). The opening up of the capital account, in combination with the stabilisation programs, prompted a surge in capital flows which sustained consumption and, to a lesser extent, investment booms, accumulating real and financial disequilibria in the economy which were reflected in a deterioration of activity and an overvaluation of the exchange rate (see graph 12). Also, the softening of the external constraint led, in some cases, to a certain relaxation of policies and a slowdown in reform. Finally, external investors failed to assess the situation in time and to discriminate among countries (although the markets' capacity for discrimination seems to be improving of late). These ingredients were at the root of the series of financial crises which plagued Latin America after 1994 and which spread to the region in the form of contagion. Financial crises have indeed been frequent and damaging. Arguably, vulnerability is to some extent unavoidable. Some of the structural traits of the region mean a high degree of vulnerability is entrenched, such as the debt burden mentioned above, but other traits have even deeper roots in the region. In particular, the large financing requirements in order to sustain the process of development and also other imbalances,
Latin America: prociclicality of fiscal policy

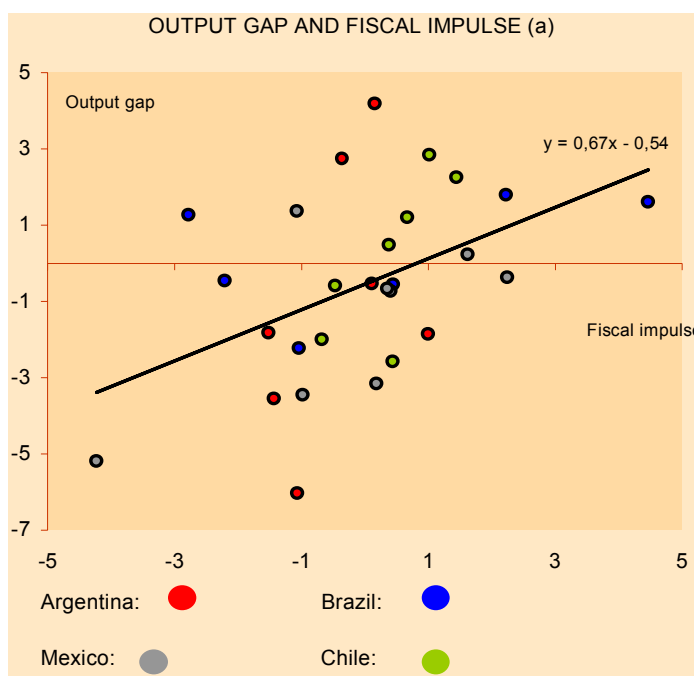

Sources: Martín Machuca (2001)

(a) The black line represents the regression between the two variables.

GRAPH 11

Emerging economies: indicators of vulnerability
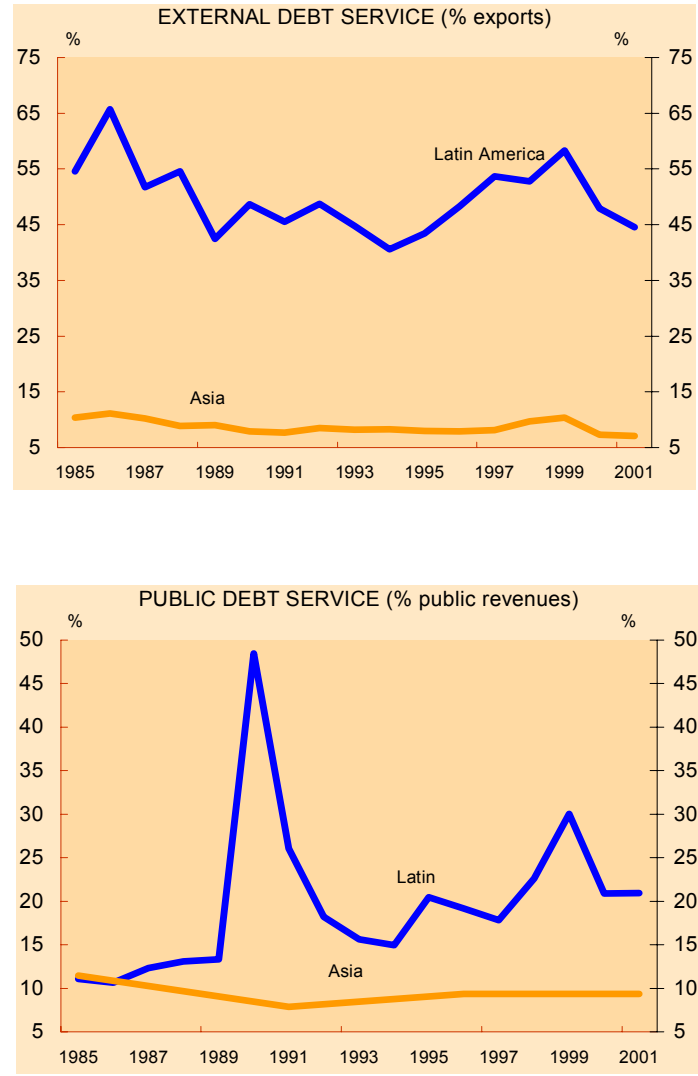

Source: IMF.

(a) Comprises 7 countries 
Latin America: external disequilibria
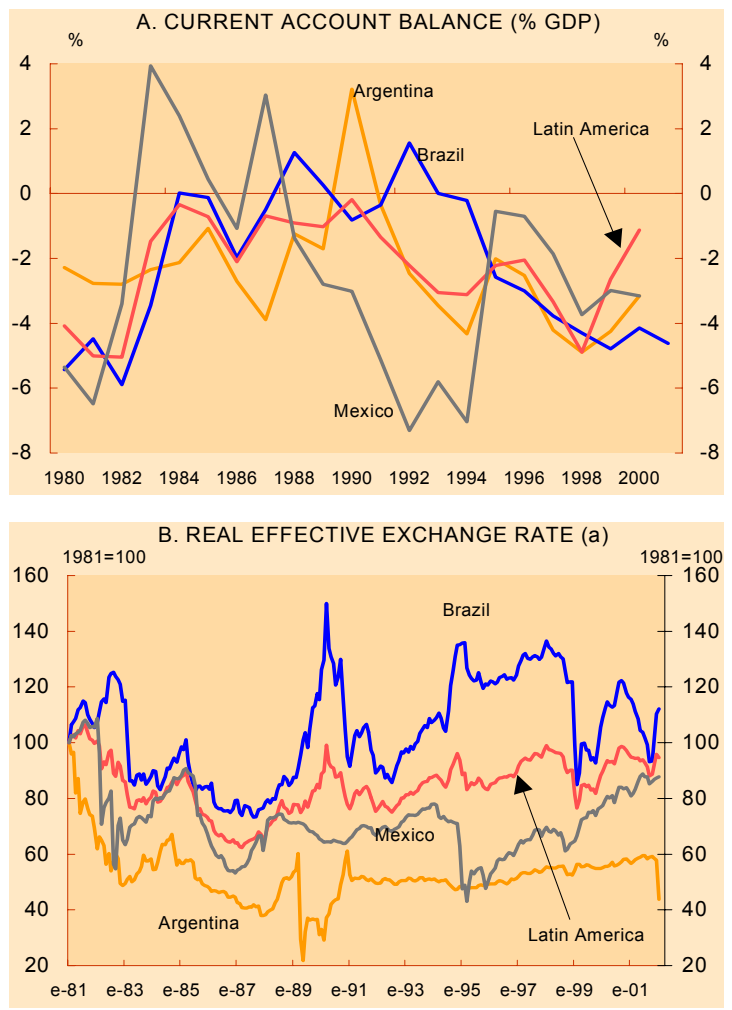

Sources: own calculations, IMF and JP Morgan.

(a) Calculated with CPI against 27 trade partners. $1994=100$. An increase signals a lost of competitiveness.
Saving and investment
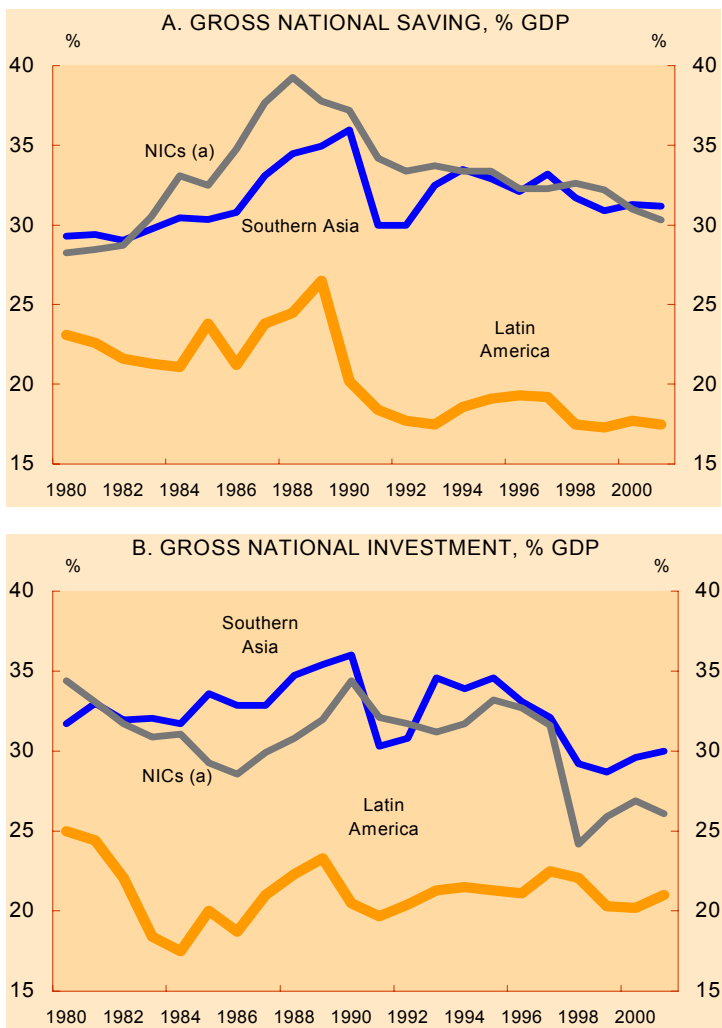

Sources: IMF WEO database.

(a) South Korea, Taiwan, Hong Kong and Singapore.

compounded by the low rate of savings (which are, tellingly, much lower than in East Asia and even than in developed countries, as graph 13 displays), generate a large financing gap. This gap is moreover, financed in general by means of high interest rate spreads, due to the accumulated financial heterodoxy from the past and the resulting uncertainty. In addition, these large financing needs go together in many cases with a large share of foreign currency liabilities.

In any case, this sensitivity to international financial markets' sentiment means a sustained extra effort must be made to achieve the highest possible degree of economic discipline so as to reduce risk premia and, ultimately, the vulnerability of the economy.

\subsection{Structural reform and institutional strengthening ${ }^{15}$}

Reforms in Latin America have been far-reaching and have extended to all spheres of economic activity. According to some authors, like Rodrik (1996), Latin America has adopted more trade and financial liberalisation policies in recent years than the East Asian countries in three decades.

\footnotetext{
${ }^{15}$ This section partly builds on BID (2001)
} 
Probably, the higher reliance on foreign capital has contributed to the impetus of the process. We follow the outline of the previous section, concentrating on four main areas of reform: economic liberalisation, financial markets, labour markets and social capital.

\section{Economic liberalisation}

Advances have been remarkable not only in the trade sphere (see above), although the delay in initiating the reforms still places Latin American countries behind on many measures of economic liberalisation. The laws and regulations to provide for the smooth functioning of market principles are in place. One of the most visible components of the strategy to reorganise the apparatus of the state, simplify government activities and enhance efficiency has been the extensive resort to privatisation. This has focused on utilities, telecommunications and the banking system. However, in practice, there are still many difficulties in effectively applying market principles. The main weaknesses are the fragility and scant effectiveness of public institutions, sometimes coupled with loopholes and a lack of means to enforce regulations. Unfortunately, in recent years, an additional risk is materialising in some countries of the region: the reversal of the regulatory framework and the infringement of property rights. This is a worrying development since it impinges on current activity and on future expectations by eroding trust.

\section{Financial markets}

The financial system in the region has undergone a complete turnaround ${ }^{16}$, as observed in graph 14. Several traits which constrained the financial system in the past have been modified: targetedcredit programmes and interest rate controls have been mostly suppressed; reserve requirements, traditionally very high as an implicit tax on financial intermediation, have been reduced to below $20 \%$; international standards of regulation and supervision have been adopted; the share of public banks has dwindled, mostly through privatisation, and the share of foreign-owned banks has increased substantially, as shown in the same graph. This set of reforms provided for a significant increase in the bancarisation of the economy. The increasing stock of domestic debt, the development of domestic institutional investors (the mushrooming of private pension funds is the most relevant example of this), and more active and sophisticated debt and monetary management by the authorities is contributing to widening the base of the domestic capital and money markets, which nevertheless remain relatively small. These developments are positive, but there is still a long way to go to achieve a satisfactory level of financial development that encourages saving and allows for a better intermediation of resources, reducing external vulnerability. After all, there are still some important areas of improvement, and some of the advances (like the improvement of regulation or better screening of customers) may hamper credit growth in the short term. Moreover, as the crises in the decade testify, some banking systems in the region are still fragile, but experience shows that properly managed banking crises can be Schumpeterian, in the sense of setting the basis for a stronger financial system in the future. 

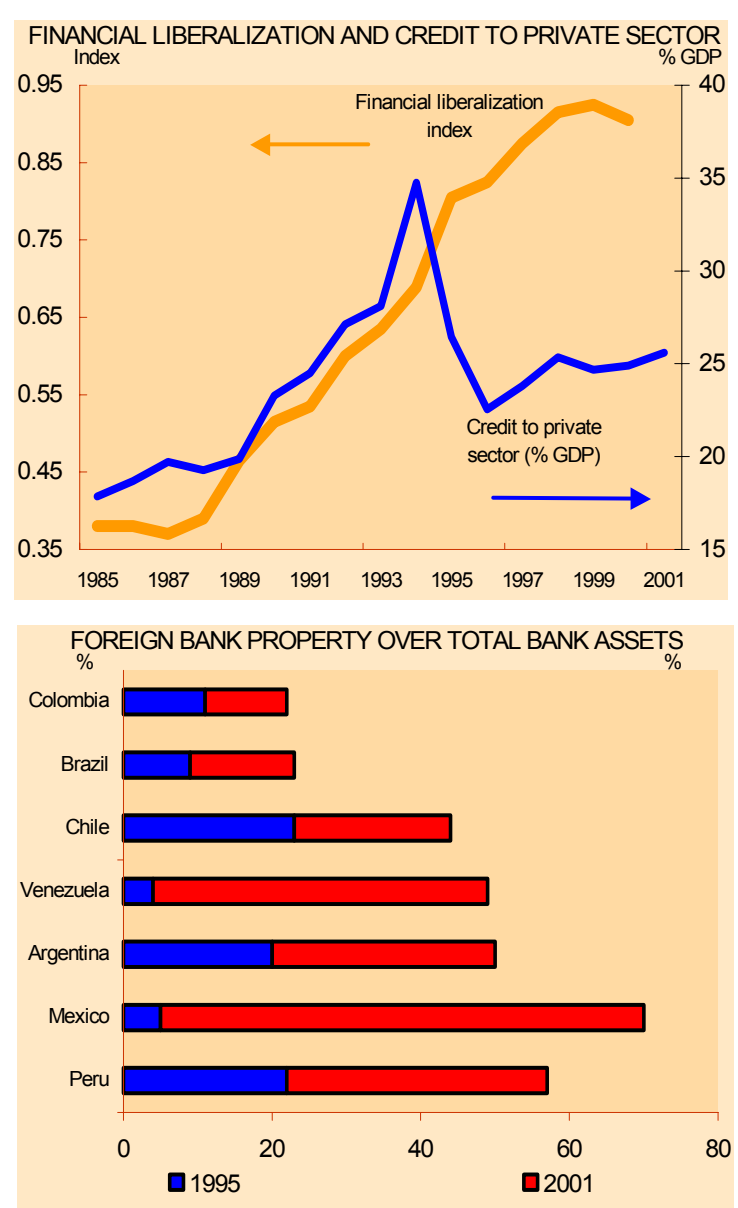

Sources: IADB and IMF.
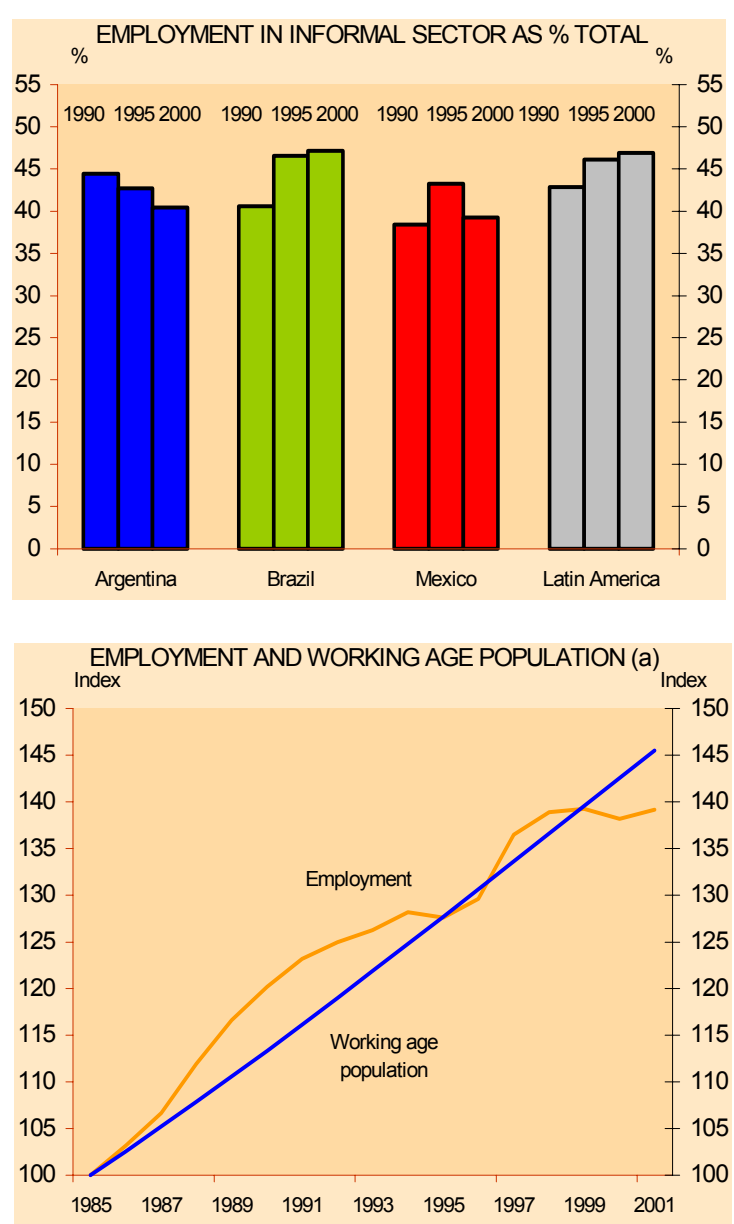

Sources: ILO, and own calculations from IMF and ECLAC. (a) Index base $1985=100$. Population 15-64 years old.

\section{Labour markets}

The labour market is the area where reforms have been less satisfactory. Only in a few countries has labour reform been significant. The main feature of many Latin American labour markets is their extreme duality. A formal sector where firing and non-wage costs are very high, well above those even in Europe in many cases, contrasts with an informal/underemployment sector which represents a large share of employment in many countries (graph 15), and which in a certain sense is very flexible. Therefore, an effort to increase the flexibility of the formal sector, coupled with well-defined incentives for the informal sector, would allow for a progressive integration of both, observing the principles of efficiency, flexibility and fairness.

${ }^{16}$ See a more detailed analysis in Latin American financial development in perspective by Banco de España, also presented in this workshop. 


\section{Human and social capital enhancement}

Reducing the capital gap at all levels in Latin America is a key objective, not only in terms of private physical capital but also in terms of human capital (education) and infrastructure. The advances in the last decade have been important and positive, as graph 16 evidences in the case of education, but the effort must be sustained to bridge the still-large gap. The situation in terms of health standards and pension systems can in general be improved. These aspects, by themselves, would grant an essential role to public spending in Latin America in order to improve the stock of social capital, but the effects of the gaps in social capital also have a central impact on income distribution, poverty and social cohesion (see below).

The increase in and better management of fiscal resources play a pivotal role in this context; hence the importance of extensive fiscal reforms to increase the fiscal base and streamline the tax structure. Some steps in this direction were taken in the decade. The tax system was thoroughly

GRAPH 16

Latin America: education indicators

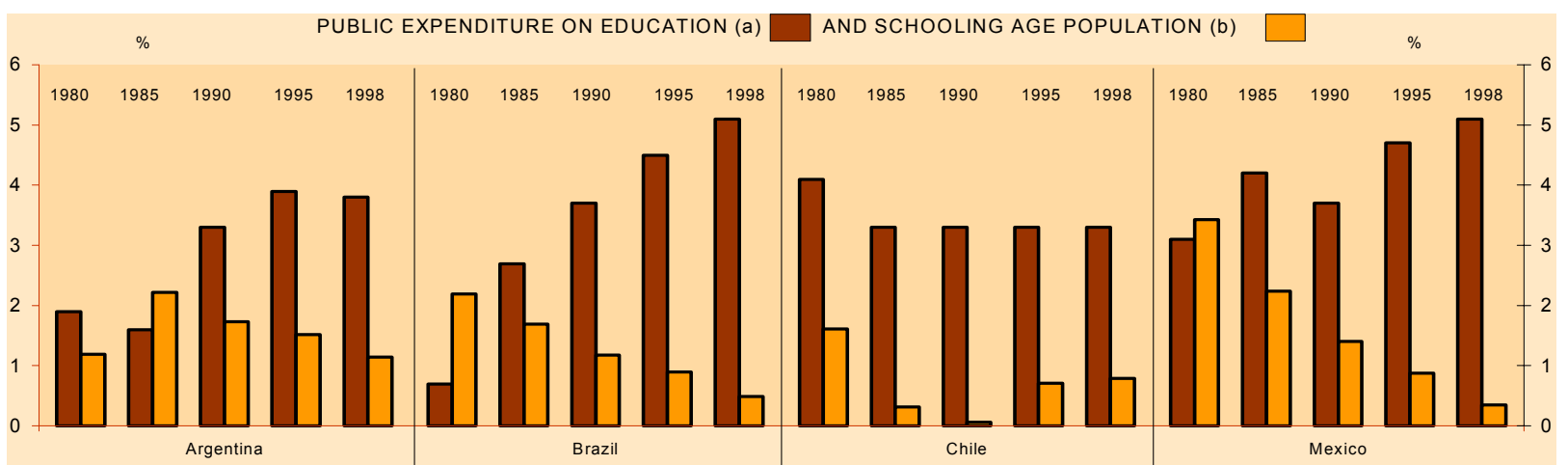

Sources: ECLAC.

(a) Percentage of GDP

(b) Growth rate of population 5-24 years old

Latin America: income distribution

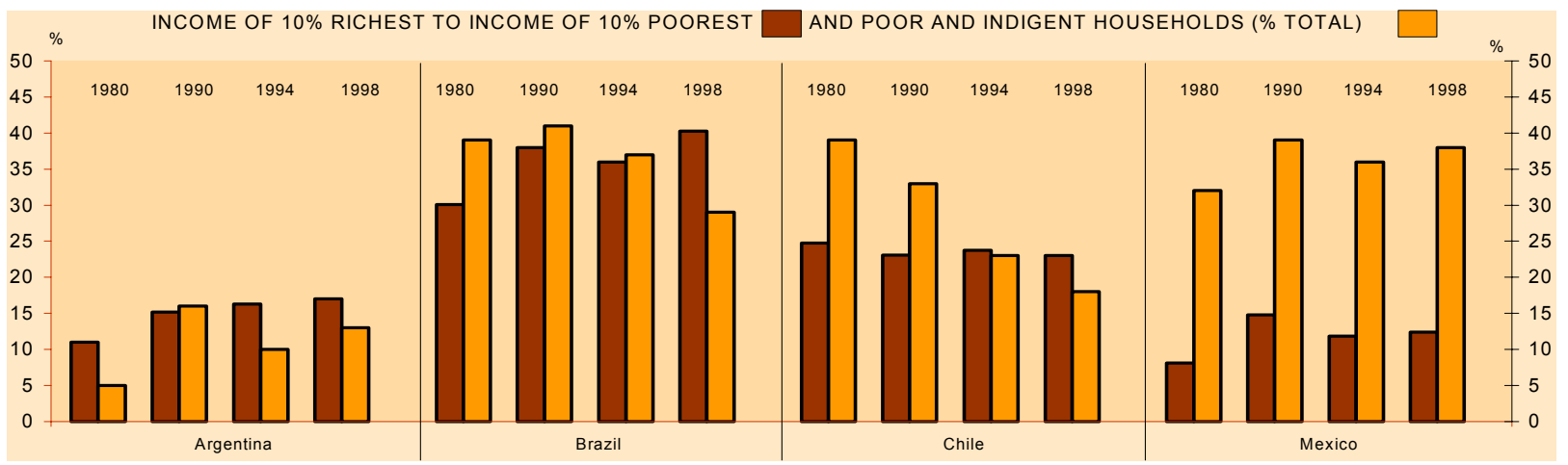

Sources: ECLAC 
overhauled: the share of tariff revenues shrank (from $29 \%$ to $16 \%$ in the nineties); VAT systems were adopted in many countries; marginal rates on profits were reduced and there were serious efforts to improve tax administration and revenue ${ }^{17}$. However, over recent years reforms have been stalling and the trend towards fiscal decentralisation, despite improved co-responsibility mechanisms in some cases, is creating some problems with severe consequences for the stability of certain countries.

\subsection{Real convergence}

The outcome of a decade of reforms can be judged as mixed. As reviewed, there have been substantial breakthroughs in many spheres, from macroeconomic stabilisation to the liberalisation of the economy, the improvement of the financial system and greater integration into world markets. Certain exceptions aside, these changes have hardly translated into advances in real convergence or a better distribution of income, and the goal of achieving a path of sustained growth has been jeopardised by the persistent vulnerability of the region to financial crises. Nonetheless, as we will emphasise in the next section, the culprit cannot be the reform process. Rather, as the cases of those early (Chile) or intense (Mexico) reformers show, reforms can be said to have not gone far enough, or to have not been comprehensive enough or to have had neither the conditions or time to take root.

Regional growth stood at $3.3 \%$ in the nineties, a meagre $1.5 \%$ in per capita terms, which has in general not allowed for real convergence with the developed countries. Furthermore, this performance comes after a decade -the lost decade- of negative growth in per capita terms, which emphasises the unsatisfactory performance of the Latin American economies, taken as a whole.

At the root of this outcome is productivity growth. Although labour productivity growth was $1.75 \%$ in annual terms during the past decade in the region, total factor productivity growth was substantially lower ${ }^{18}$. Only the Southern Cone economies, and the odd other country, recorded relevant growth in total factor productivity. This moderate outcome, in terms of labour productivity, is explained by the growth in employment, at an annual rate of around $1.7 \%$, which has in any case had to cope with a large increase in the working age population (see graph 16). Therefore, given such a high demand for new jobs, advances in productivity are only possible with high and sustained rates of growth.

Another worrying outcome of the decade of reforms in Latin America, given the lagged starting point, has been the scant progress in income distribution, mainly in the second half of the decade, highlighting the effects of the crises on low-range incomes (see graph 17). Arguably, extreme

\footnotetext{
17 It could be argued that some of the fiscal reforms have had perverse effects on distribution, because some of the changes in taxes (reduction in marginal rates on income and profits, increase in indirect taxation) have had a regressive bias. This outcome should be compared with the positive effects on fiscal compliance that the reforms may have brought about.

${ }^{18}$ See IADB (2001)
} 
differences in income have prevented the spreading of the middle classes in Latin America, thus eroding one of the most important bases for the cohesion and articulation of society and the chances of institutional consolidation. Addressing these issues more decisively would help to overcome some of the structural drags mentioned above, foster social and political stability, and reinforce the commitment to market principles and reforms.

To all these elements we must add the competitiveness position of the LA economies. Competitiveness, defined broadly by the 'quality of investment environment' and which can be interpreted as a leading indicator of potential future growth, also put Latin America in a relatively low position as graph 3B illustrated, underscoring the sustained effort still to be made.

\section{Europe versus Latin America}

From the previous two sections it is clear that, while certain aspects of the European processes of integration and convergence (real and nominal) are somewhat similar to those in Latin America, other aspects are relatively specific to the European case and hardly applicable to other regions. In particular, differences are most pronounced in the institutional framework.Identifying both types of traits (common, on one hand, and specifically European, on the other) is essential in attempting to define the limits of the parallelisms and analogies between both areas.

One of the most characteristic aspects of the European process is the existence of a well-defined incentives structure rooted in a robust institutional design. As shown in section 2, the European Union, throughout its almost half a century of history, has developed an institutional framework much stronger than any other free trade area in the world (it has even been criticised for being too bureaucratic). This confers strong institutional backing and soundness of framework on the EU, thereby helping consolidate advances. An international legal umbrella locks in the progress made, making reversals very unlikely (the other side of the coin obviously being a transfer of sovereignty to the supranational level). Strong institutional arrangements are deemed crucial to co-ordinate the process of reforms and real convergence. Given that Latin American countries lack the sort of framework that the European periphery enjoyed, persevering with a strong, decisive and continuous political impulse to proceed in terms of integration, stability and reforms becomes paramount, in spite of the fact that the risk of reversals is higher, since there is hardly any external device to lock in the gains made.

Having closer and closer integration as an objective, the free market ideal firmly rooted in legislation and political co-operation as an increasingly ambitious target all contributed to strengthening European integration. It is certainly important to bear in mind that the European project was initiated more than fifty years ago, whereas Latin American integration is much more recent. Furthermore, there are differences in the sequence of trade integration, nominal convergence and structural reforms: whereas in Europe, roughly speaking, trade came first, nominal convergence later and structural reforms more recently (albeit with considerable overlapping and at a far from uniform pace), in Latin America the three took place more or less at the same time over the 90's. In this regard, another difficulty in comparing both processes lies in the insufficient perspective for the case of Latin America. Despite this, the rest of this section 
attempts to draw some lessons from the comparison between both areas in nominal convergence, structural reforms and real convergence.

As integration proceeded, macroeconomic stability became an increasingly important policy objective. From a historical perspective, the relevance of macroeconomic stability as an economic policy objective has undergone fluctuations related to those in economic theory paradigms and in economic policy-making, against the background of the generalised increase in inflation in the 70 s and the return to more orthodox policies in the $80 \mathrm{~s}$. For the purpose of this paper it should be borne in mind that these debates took place in Europe in a context of increasingly stable exchange rate regimes in which German monetary policy played a central role as an anchor for price stability. In a world of generalised floating, European countries showed a strong reluctance to float, which is easy to understand given that excessive exchange rate volatility was seen as a threat to the deepening of the common market, the most highly valued European achievement. But the process was neither harmonious nor devoid of crises. The tensions between domestic policy objectives and external constraints led occasionally to volatility and market turmoil. But little by little European countries other than Germany -the anchor of the ERM- adopted price stability as the basic goal of monetary policy, as awareness increased that price stability was a prerequisite for sustained economic growth.

This explains why, when the Maastricht Treaty was drafted in the late 80s, macroeconomic stability became a basic element of both convergence towards monetary union and the economic policy framework of EMU. Price stability became the fundamental goal of an independent European Central Bank; sufficient convergence in inflation rates was a necessary (but not sufficient) condition for countries joining EMU; and a stability and growth pact was added as an element to ensure fiscal discipline among member countries.

In this sense, the institutional framework reviewed in section two aimed at ensuring macroeconomic stability in Europe is unique in the world. This is particularly relevant concerning the incentives for peripheral countries to achieve and maintain nominal stability. These countries, which tend to have a higher growth potential than core countries, have traditionally been limited in their economic progress by their propensity towards instability, which has periodically induced crises and reversals in their progress.

The incentives peripheral EU countries faced to pursue stability-oriented economic policies were particularly strong in the run-up to EMU. The convergence criteria played a very important role in pushing policies in peripheral countries onto the stability track, as evidenced in graph $2 \mathrm{~A}$. Not only were these countries required to keep inflation low, but also to maintain sound public finances, long-term interest rates below a certain threshold and a stable exchange rate, the two latter criteria implying that nominal convergence should not only be achieved in terms of contemporary inflation rates, but also be viewed by financial markets as balanced and sustainable.

It is worth noting that this sort of external framework is currently benefiting the accession countries of Eastern Europe on their course towards the EU, and this will be more intensely the case in the coming years. . On the contrary, the advantages of this set-up do not apply to Latin American countries, which highlights the merits of the progress made in their case. For the purposes of this paper it is important to note, however, that nominal convergence requirements were not so 
different in both areas, in that the markets were in any case the judges of convergence. In the case of the EU, countries with good policies will be rewarded with low long-term rates and stable exchange rates and, once in EMU, this virtuous circle will be additionally driven by convergence towards the lowest real interest rate (as actually occurred). Although EMU's institutional framework is inapplicable to Latin America, fulfilment of the convergence criteria by EU peripheral countries played an analogous role to that represented today by the achievement of the investment grade rating by Latin American countries. The policies pursued in both cases were similar, as were the rewards, the main differences being that EMU "locks in" some of the gains (but only to a certain extent; losses of competitiveness would penalise countries with bad policies in EMU as well) and, more importantly, it also locks in expectations, reducing uncertainty. Furthermore, EMU provided a focus point and triggered a momentum towards nominal stability in Europe that Latin American countries do not have.

As already explained in section 2, another interesting aspect of nominal convergence in EMU is the role played by emulation in creating the incentives for the right policies in peripheral countries: the costs of indiscipline rose perceptibly as an increasing number of countries achieved nominal stability. Certain arrangements for the surveillance of economic policies (BEPG, Stability and Growth Pact...) also showed the importance of "peer pressure" among EU countries as a disciplining device. This element is only very indirectly present in the case of Latin America. Countries which pursue the right policies are expected to be rewarded by international financial markets, benefiting from lower costs of financing and more capital inflows (a very strong incentive in a region so dependent on foreign capital). Thus, by creating a sort of competition for foreign funds, a certain kind of positive emulation may appear. Yet it is also possible that countries with undisciplined policies may seek a comparative advantage by resorting to competitive depreciations or devaluations, thus inducing contagion to other countries. There is a risk therefore of "negative emulation", as a result of contagion from crises via the exchange rate being prevalent as compared to "positive emulation" via international financial markets rewarding the countries following sounder policies.

As mentioned above, the exchange rate anchor was instrumental in facilitating nominal convergence for European peripheral countries, despite tensions, drawbacks and volatility in certain periods. In the case of Latin America, the exchange rate regime has been one of the most difficult -and often controversial- aspects of convergence efforts. Countries in the region have attempted to use the exchange rate anchor as a tool to achieve nominal stability. It proved useful in some cases for a certain period, but in the second half of the $90 \mathrm{~s}$ it became clear that explicit unilateral exchange rate pegging regimes are extremely vulnerable to destabilising capital flows.

The lesson European countries learned in the early 90s with the EMS crisis was similarly taught in Latin America a few years later. But one key difference is that, whereas European countries were able to achieve de facto exchange rate stability after 1995, thanks not only to sound and convergent policies, but also to the stabilising impact of EMU expectations, Latin American countries, without such an anchor, were subject to destabilising capital flows and in general moved to floating regimes with an internal anchor in the form of inflation targeting (or to dollarisation in a few cases). It is difficult, and to some extent futile, to assess which of the multiple current 
exchange rate strategies best serves the stability goal; what actually matters is that the whole set of macroeconomic policies should consistently and decisively pursue this objective, so as to attain a stable environment and to achieve a positive verdict from the markets.

Fiscal policy is another "pillar" of a stability-oriented economic policy. In Europe there is a framework to ensure fiscal discipline, but in the Latin America area, as mentioned in section 3, a number of factors led to a pro-cyclical pattern in the fiscal stance. Mechanisms for granting a more stabilising role for fiscal policy are essential to reduce cyclical swings and ensure permanent gains in terms of nominal stability.

In Europe, as well as in Latin America and other emerging markets, crises were often rooted in an inadequate policy mix. Loose fiscal policies in countries engaged in a real and nominal convergence process overburden monetary policy and lead to very high interest rates, which attract capital inflows. In the ERM, the existence of a very credible upper floor for traditionally "weak" (peripheral) currencies limited the scope for a nominal exchange rate appreciation, but competitiveness deteriorated steadily as a result of persistent inflation differentials. It is worth keeping in mind that the ERM was by far the strongest mechanism for exchange rate stabilisation that has ever existed after the move to floating in the early $70 \mathrm{~s}$, due to its formal multilateral nature, the prescribed symmetry of intervention obligations and the existence of financing mechanisms for interventions. And, despite this, the ERM was subject to very strong pressures and had to resort after the 1992-93 crises to the widening of its bands. It is not surprising, therefore, that maintaining unilateral exchange rate pegs has been so difficult in emerging markets in the second half of the 90s. When imbalances in real exchange rates and the current account accumulate, a crisis becomes unavoidable. In some cases, an inappropriate sequencing of liberalisation of the capital account exacerbated these problems, by increasing vulnerability to the shifting mood of international capital markets.

An important lesson, however, both from the European and the Latin American cases, is that even when the policy mix is balanced and the sequencing of liberalisation is adequate, countries and currencies are exposed to volatile capital flows, partly for exogenous reasons, such as changes in the appetite for risk of players in international financial markets. Therefore, developed domestic financial markets act as a buffer for external financial shocks. The deeper they are, and the lower the dependency on external capital flows, then the less countries would suffer from such volatility. In this regard, Latin American countries' insufficiency of saving and strong dependency on external financing render them extremely vulnerable to such reversals in international capital flows.

The differing relevance of the supranational institutional framework has been identified as a key difference between both regions. Clearly, the institutional elements of the European process that have helped peripheral countries in their drive for convergence are missing in Latin America. But in no way does this imply that convergence occurs without any effort. Countries need to assume the stability objectives and policies need to be supported by the population. Even in EMU, and given a stability-oriented monetary policy, low inflation rate differentials do not come about automatically as a result of the mere existence of a single currency. Stability-oriented policies need to be pursued in any economic regime. But the incentives in EMU for adopting a framework conducive to price stability are, admittedly, particularly strong. In this regard, and although such processes 
are necessarily slow, closer trade integration in Latin America might over time incorporate institutional elements akin to those of the EU. In that case this avenue would have to be pursued with perseverance, sustained political resolve and clear popular support.

Europe used many instruments and devices to help achieve nominal stability: co-operative exchange rate arrangements, convergence criteria for EMU, legislation enshrining price stability at the core of EU policy targets, and other institutional mechanisms to impose sound fiscal policies like the stability pact. All these mechanisms help achieve and maintain low inflation and may under certain circumstances reduce the cost of doing so. But they do not replace the basic prerequisite of political consensus and social support as the main conditions to achieve nominal stability. Stability policies always require sacrifices in the short term and entail certain costs, which are only feasible with sufficient support from the majority of the population. Transparency, a clear communication policy and a constant effort to explain the advantages of a sound and stable economic environment to the population are in any case necessary, and cannot be replaced by institutional devices or international suprastructures. Although the supranational umbrella has sometimes been used in the EU as a useful lever to impose unpopular policies, it is very risky to abuse such a strategy, since it can turn against the European project itself, to the extent that the citizens might ultimately identify the European project with the reiterated imposition of unpopular policies.

From the above it is obvious that the lack of an external lever to impose stability policies calls for stronger political commitment and deeper-seated social backing in Latin America, both these being very demanding in countries where social needs are often huge. Latin America has, however, one advantage in this regard: that the population are aware of the very high costs of exuberant policies (monetary or fiscal), because they have often paid the price for them in the past.

But are there any devices that can play a role in Latin America similar to that played by the EU institutional structure in the case of the European periphery? IMF programmes have been suggested as a substitute. To what extent can the IMF in Latin America play the role the EU institutional umbrella has performed for peripheral countries? The analogy cannot be taken too far. One key difference is the fact that IMF programmes are applied to countries in an already difficult situation, and cannot be regarded as a convergence tool in normal situations. "Ownership" of the strategy is another issue: the EU institutional setting has been adopted by all the member countries and is enshrined in their constitutions, whereas IMF programmes are often seen as externally imposed. The balance between conditionality of Fund financing and ownership of the programmes by the country is one of the basic questions of international financial architecture, which is still under discussion. For all these reasons, it is difficult for them to replace the sort of 
external anchors as those used by peripheral European countries ${ }^{19}$.

Perseverance in nominal stability (and reform) is pivotal to maintaining a sound environment, but continuous political resolve and social support are also required, all the more so when there is no supranational umbrella, like in Latin America, as argued above. Adequate institutional devices , such as an independent central bank, no monetary financing, prudent fiscal norms ${ }^{20}$, mechanisms ensuring compatibility between fiscal federalism and discipline, transparency, etc. may help in creating an environment conducive to nominal stability.

One lesson from the $80 \mathrm{~s}$ and $90 \mathrm{~s}$, in Europe and elsewhere, is that the flexibility of markets and adaptability to changing circumstances are also essential ingredients of price stability. The dilemma between stability and efficiency as policy objectives is a false one, as there is no substitutability between them in the long term; on the contrary, they tend to reinforce each other, in the sense that for stability to be preserved, the economy should be able to adapt to the changing pattern of demand in increasingly globalised markets. Furthermore, an open, competitive and efficient economy is the best means to ensure price stability. And conversely, a stable macro environment is crucial for maintaining efficiency. The increasing consensus on this approach led many countries in Europe and in Latin America to focus increasingly on structural reforms as a key ingredient of stability-oriented policies.

For peripheral and emerging markets to be able to compete in a globalised economy, an appropriate stock of human and capital infrastructure is essential. Otherwise it would be impossible for them to compete with "core" countries ${ }^{21}$. Public spending policies play a crucial role in this regard, but for the fiscal effort to be undertaken without deteriorating external financial constraints, a sufficient fiscal base is needed. EU peripheral countries made a considerable effort in this regard, partly with financial support from EU resources, but mostly thanks to their own effort, which required far-reaching fiscal reforms. This element is weak in Latin American countries, which calls for relatively ambitious fiscal reforms, aimed at enhancing equity and increasing social cohesion. Investment in infrastructure and education will boost growth possibilities and long-term productivity.

As mentioned above, a deep, sound and resilient financial sector is also essential to cope with external vulnerability. In particular, policies geared to fostering saving would reduce the strong dependency of Latin American countries on external financing. The recent development of private pension funds is encouraging in this respect.

In labour market reforms, European countries (including the periphery) are embarked on a process of flexibilisation, which is expected to allow them to reduce an unemployment rate clearly

\footnotetext{
${ }^{19}$ It should be noted that some novel devices such as the IMF's Contingent Credit Lines (CCLs), which are granted to countries that demonstrate the health and stability of their economic situation through the fulfilment of quite stringent economic requirements, , may play a somewhat analogous role to the convergence criteria in Europe. However, CCLs have not been sought by the target countries in Latin America, due to the fear that they are interpreted as signalling underlying weaknesses.

${ }^{20}$ See Von Hagen (1996)

${ }^{21}$ See Krugman (1995)
} 
higher than other industrial areas. Latin American countries are in general characterised by a dual labour market, with a very flexible informal sector and a very rigid formal sector. Reforms of the latter in the direction of greater flexibility should keep pace with a more inclusive regulation of essential aspects of the former.

Concerning structural aspects it is important to remember that, as in the case of nominal stability policies, the European framework helps consolidate them and keep the legal and institutional framework stable. In this regard, it tends to protect peripheral EU economies from the risks of reversals in the legal and institutional structure, a protection which is much more complicated in the Latin American case.

Real convergence results show that ten years of reform in Latin America, in some cases acceptably implemented, have not been enough to place the region on a sustained track for growth. Coupled with the recent financial crises and the failure to reduce income inequalities, this has created a certain sense of disappointment in the region. Other aspects allow for more optimism. The degree of macroeconomic stability achieved is a cornerstone for growth; reforms take a long time to entrench and may have adverse effects on performance in the short run, but the evidence shows that they improve growth potential and that those countries which decisively pursue them, such as Chile or Mexico, can achieve a sustained path of growth in the medium run.

All in all, it is apparent that an extra effort is needed in Latin America, relative to Europe, to attain the fruits of reasonable policies. Some key elements that have contributed to the success of the European periphery are not applicable to Latin America. But the most important lesson from Europe is that there is no substitute for the sustained pursuit of policies aimed at achieving macro stability and improving the efficiency of the economy, and that popular support is essential for such policies to be successful. A strengthening of domestic economic and financial institutions, a persistent commitment to macro stability and a perseverant strategy aimed at fostering the efficiency and attractiveness of these economies to foreign capital as well as at improving social cohesion are some of the main elements of this strategy.

\section{Annex 1: steps to monetary union ${ }^{22}$}

1. In 1952 France, Germany, Italy and the Benelux countries set up the European Coal and Steel Community (ECSC), the first common market for a limited number of products.

2. On 27 March 1957, the six ECSC countries signed the Treaty of Rome establishing the European Economic Community. Over a period of 12 years, a common market was to be created, starting with the gradual abolition of customs duties within the Community and the introduction of common tariffs vis-à-vis the rest of the world. The second objective was the free movement of capital and persons. In order to realise these aims various institutions with supranational powers were set up, such as the European Commission, which is the EEC's

\footnotetext{
${ }^{22}$ Based on Van Bergeijk, Berndsen and Jansen (2000)
} 
executive body, the Council of Ministers, which decides on European legislation, and the European Parliament, which has mainly advisory and monitoring powers. The EEC was launched on 1 January 1958. Also, an important aspect of the Treaty of Rome was that it also provided the basis for further co-operation in the monetary field.

3. In 1970, the Werner Plan for creating an Economic and Monetary Union was presented. Under the plan, the union was to be set up over a period of ten years. Initially, exchange rate fluctuations would to have to be contained and the first steps would be taken towards the coordination of monetary and fiscal policies. In the last stage, the currencies were to be locked together, and a monetary and budgetary authority would determine monetary and economic policy. But differing views in Germany and France about the way forward resulted in an abandonment of the plan.

4. In March 1972, the EEC Member States decided in Basle to adopt margins of at most $\pm 21 / 4$ per cent between their currencies, and to provide one another with intervention support for their currencies and no longer in dollars. This compelled the central banks to co-operate more closely. It was the birth of the snake in the dollar tunnel. In 1973, The European Monetary Co-operation Fund (EMCF) was set up to provide intervention support.

Partly because the oil crisis hit some countries harder than others, currencies were continually leaving the snake, to re-join some time later. In 1973 the snake decoupled from the dollar. That year, it was decided that a "European Summit" of the Heads of State or Government, i.e. the European Council, be held every six months to boost political convergence. The lack of convergence of the economic and monetary policies of Germany and France, in particular, gave rise to diverging developments in inflation rates, and thus continued to fuel pressures in the foreign exchange markets.

5. Continuing foreign exchange unrest compelled the Member States to work more towards monetary co-operation. During the Copenhagen summit of 1978, a committee of senior civil servants from Germany, France and the United Kingdom was called on to draw up a concrete plan. German Chancellor Helmut Schmidt and French President Giscard d'Estaing took the initiative to boost co-operation at least on the foreign exchange front. This resulted in the European Monetary System (EMS) which took off on 13 March 1979. It was a new system of fixed but adjustable exchange rates, meant to create a zone of monetary stability although it was not intended to be a stepping-stone towards economic and monetary union. Only the UK did not join from the outset. One of the novelties of the EMS was the introduction of the European currency unit, the ECU. Many capital-account restrictions remained in force. Nor was there an agreement to eliminate national policy differences. Fiscal policies and inflation rates continued to diverge substantially in the early 1980s. Germany favoured a stability-oriented policy, while France pursued an expansionary policy. As a result, the EMS, like the snake, had to cope with many realignments in its early phase.

6. The year 1983 may be seen as an important turning point in the history of the EMS. France made a U-turn when the authorities decided to give priority to a stable exchange rate between the French franc and the Deutschmark as a way of enhancing price stability, as in Germany.

7. In 1985, France and Germany presented a joint proposal for greater political co-operation. During an Intergovernmental Conference that same year, the Community's ten Member States 
(Greece had joined in 1981) agreed on the necessary Treaty amendments, to be laid down in the Single European Act. It was of utmost importance that majority voting should be reinstated for decisions concerning a wider range of issues. In 1986, Spain and Portugal became EC members. The European Commission published a White Paper on which trade barriers (physical, technical and fiscal) still needed to be removed before the Single Market could be completed by end-1992. It was furthermore decided to abolish the remaining capitalaccount restrictions in 1990. Now it was time for a more dynamic approach to the completion of Economic and Monetary Union (EMU).

8. At the 1988 Hannover summit it was decided that stage one of EMU would commence on 1 July 1990. A committee made up of central bank governors, chaired by Mr Delors, then President of the European Commission, was given a mandate to draw up concrete proposals to that end. The Delors Report (1989) made a proposal for irrevocably fixed exchange rates, a single monetary policy, a European system of independent central banks, and a European Central Bank striving for price stability. So far the plan was very much like the 1969 Werner Plan. EMU was to be realised over a period of years.

9. Stage One of Economic and Monetary Union aimed to strengthen both monetary and nonmonetary co-operation within the existing framework. This stage formally commenced on 1 July 1990. Any remaining capital-account restrictions were abandoned in most Member States although four member states (Greece, Ireland, Portugal and Spain) were allowed a transitional period until the end of 1992. In order to achieve an area without borders by 1 January 1993, it was agreed to adjust value added taxes and excise duties. A year later the European Economic Area (EEA) was created, under which Norway, Sweden, Finland, Iceland and Austria joined the free single market of the European Community. This structure enabled the free flow of goods and services, capital and people within Europe without altering the acquis communautaire (the body of legislation) of the European Community. However, practically speaking it took until the end of 1997 before passport controls at intra-EU borders were lifted under the Schengen agreement.

10. Stage two of EMU (1994): economic convergence. One goal of Stage Two of EMU was to prepare the establishment of the European Central Bank by creating the European Monetary Institute (EMI). Another goal of Stage Two was to achieve economic convergence between the Member States following the requirements of the Maastricht Treaty (signed in February 1992 and effective from November 1993). Under the terms of the Treaty, the Member States committed themselves to seeking to reduce excessive deficits during Stage Two. Member States would have to fulfil so-called convergence criteria before adopting a single currency in Stage Three of EMU. This requirement was combined with the notion that Stage Three would start in 1999 at the latest, with however many Member States might have satisfied the criteria by that time.

11. Stage Three of EMU: the exchange rates were irrevocably fixed on the last day of 1998, enabling the monetary union to be launched on 1 January 1999. The euro was established as the single currency for 11 European Countries and the monetary policy of the ECB began operating.

\section{2002: Introduction of the euro notes and coins}




\section{References}

Alesina , A. and R. Wacziarg (1999): "Is Europe going too far?", NBER Working Paper 6883, Cambridge, MA: National Bureau of Economic-Research.

Banco de España (1997); "La Unión Monetaria Europea. Cuestiones fundamentales".

Banco de España (2001); "Using indicators to monitor real convergence". Economic Bulletin, October 2001.

Banco de España (2002), Latin American financial development in perspective, mimeo.

Committee of Wise Men (2001), Final Report of the Committee of Wise Men on the Regulation of the European Securities Markets

IADB (2001). Competitiveness. The Engine for Growth. Economic and Social Progress in Latin America. 2001 Report.

IMD, 'The world competitiveness yearbook'. Several years

Krugman, P. (1995): Technology, trade, and factor price NBER. National Bureau of Economic Research

Martín Machuca, (2001), El comportamiento procíclico de la política fiscal en América Latina, mimeo, Banco de España

OECD Observer (2001): "Economic Survey of the Euro Area, 2001".

Rodrik, D. The new global economy and developing countries: making openness work, Overseas Development Council, Policy Essay n.24.

Van Bergeijk, P.A.G., Berndsen, R.J. and Jansen, W.J. (2000): "The Economics of the Euro Area: Macroeconomic Policy and Institutions". Nederlandsche Bank.

Von Hagen, J. (1996) Budget processes and commitment to fiscal discipline" IMF. International Monetary Fund. 